\title{
Mobilized peripheral blood: an updated perspective [version 1;
}

\section{peer review: 2 approved]}

\section{Darja Karpova (D1, Michael P. Rettig², John F. DiPersio²}

${ }^{1}$ Division of Stem Cells and Cancer, German Cancer Research Center (DKFZ) and DKFZ-ZMBH Alliance, Heidelberg, 69120, Germany

${ }^{2}$ Division of Oncology, Department of Medicine, Washington University School of Medicine,, St. Louis, Missouri, 63110, USA

V1 First published: 20 Dec 2019, 8(F1000 Faculty Rev):2125

https://doi.org/10.12688/f1000research.21129.1

Latest published: 20 Dec 2019, 8(F1000 Faculty Rev):2125

https://doi.org/10.12688/f1000research.21129.1

\section{Abstract}

Enforced egress of hematopoietic stem cells (HSCS) out of the bone marrow (BM) into the peripheral circulation, termed mobilization, has come a long way since its discovery over four decades ago. Mobilization research continues to be driven by the need to optimize the regimen currently available in the clinic with regard to pharmacokinetic and pharmacodynamic profile, costs, and donor convenience. In this review, we describe the most recent findings in the field and how we anticipate them to affect the development of mobilization strategies in the future. Furthermore, the significance of mobilization beyond HSC collection, i.e. for chemosensitization, conditioning, and gene therapy as well as a means to study the interactions between HSCs and their BM microenvironment, is reviewed. Open questions, controversies, and the potential impact of recent technical progress on mobilization research are also highlighted.

\section{Keywords}

Mobilization, Hematopoietic stem and progenitor cells, G-CSF, CXCR4, VLA4, CXCR2, BM niche, Chemosensitization, Conditioning, Gene therapy

\section{Open Peer Review}

Approval Status

1 2

version 1

20 Dec 2019

Faculty Reviews are review articles written by the prestigious Members of Faculty Opinions. The articles are commissioned and peer reviewed before publication to ensure that the final, published version is comprehensive and accessible. The reviewers who approved the final version are listed with their names and affiliations.

1. Mariusz Ratajczak, Division of Hematology and Oncology, University of Louisville, Louisville, Kentucky, USA

2. Jean-Pierre Levesque, University of Queensland, Herston, Queensland, Australia Any comments on the article can be found at the end of the article. 
Corresponding author: John F. DiPersio (jdipersi@DOM.wustl.edu)

Author roles: Karpova D: Conceptualization, Writing - Original Draft Preparation; Rettig MP: Supervision, Writing - Review \& Editing; DiPersio JF: Supervision, Writing - Review \& Editing

Competing interests: DK and JFD have a patent application (PCT/US2017/059770). MPR and JFD have pending patent applications (PCT/US2017/059777). JFD is founder and advisor for Magenta Therapeutics Inc. and WUGEN Inc. He receives income from RiverVest Venture Partners and Magenta Therapeutics Inc., he receives research funding from Amphivena Therapeutics, NeoimmuneTech Inc., Macrogenics Inc., Incyte Corp., BiolineRx, Altiris, and WUGEN Inc., and he is an Advisory Board Member for Cellworks Group, RiverVest Venture Partners, and Arch Oncology. MPR serves as a consultant for RiverVest Venture Partners and has received research funding from Amphivena Therapeutics, Novimmmune, and Cantex.

Grant information: MPR acknowledges funding from the National Institutes of Health, National Cancer Institute (R50 CA211466), and the Alvin J. Siteman Cancer Center, Siteman Investment Program award, supported by The Foundation for Barnes-Jewish Hospital Cancer Frontier Fund, the Barnard Trust, and a National Cancer Institute Cancer Center support grant (P30 CA091842). JFD is supported by grants from the National Institutes of Health (P50 CA171963, Project 4 Leader) and NIH/National Cancer Institute (R35 CA210084). The funders had no role in study design, data collection and analysis, decision to publish, or preparation of the manuscript.

Copyright: (c) 2019 Karpova D et al. This is an open access article distributed under the terms of the Creative Commons Attribution License, which permits unrestricted use, distribution, and reproduction in any medium, provided the original work is properly cited.

How to cite this article: Karpova D, Rettig MP and DiPersio JF. Mobilized peripheral blood: an updated perspective [version 1; peer review: 2 approved] F1000Research 2019, 8(F1000 Faculty Rev):2125 https://doi.org/10.12688/f1000research.21129.1

First published: 20 Dec 2019, 8(F1000 Faculty Rev):2125 https://doi.org/10.12688/f1000research.21129.1 


\section{Introduction}

Discovered by pure chance in patients recovering from chemotherapy almost 45 years ago $^{1}$, the phenomenon of hematopoietic stem cell (HSC) mobilization has transformed the clinical practice of HSC transplantation ${ }^{2}$. It has further extended to indications beyond HSC collection, including mobilization-based chemosensitization, conditioning, and gene therapeutic approaches, which are areas of intensive research. Better understanding of the pathways governing HSC trafficking can provide important insights into how stem cell localization within the bone marrow $(\mathrm{BM})$ is regulated, which explains a continued need for basic research on mobilization to define the underlying molecular and cellular mechanisms.

In mammals, the first definitive HSCs arise in several intra and extraembryonic tissues from which they first migrate into the fetal liver ${ }^{3,4}$. Following expansion in the fetal liver, HSCs continue their journey towards the BM, where the overwhelming majority of adult HSCs are subsequently found in their unique, specialized environments, the $\mathrm{BM}$ niches ${ }^{5,6}$. Interestingly, despite the dramatically reduced migratory activity upon BM colonization, a small fraction of adult HSCs can be found in the peripheral circulation at any given time ${ }^{7-9}$. Even though random leakiness of BM retention pathways cannot be excluded as a cause, the regularity of this physiological HSC egress ${ }^{10-12}$ implies a biological function. The number of HSCs in the circulation at steady state can be substantially augmented by a wide variety of endogenous and exogenous stimuli such as growth factors $^{13-20}$, chemotherapy ${ }^{1,21-23}$, chemokines $^{24-27}$, chemokine and integrin receptor agonists and antagonists ${ }^{28-31}$, bioactive lipids ${ }^{32,33}$, exercise $^{34,35}$, infection, and inflammation ${ }^{36,37}$ (Figure 1). This enforced egress of HSCs into peripheral blood is called

\section{Preclinical Models:}

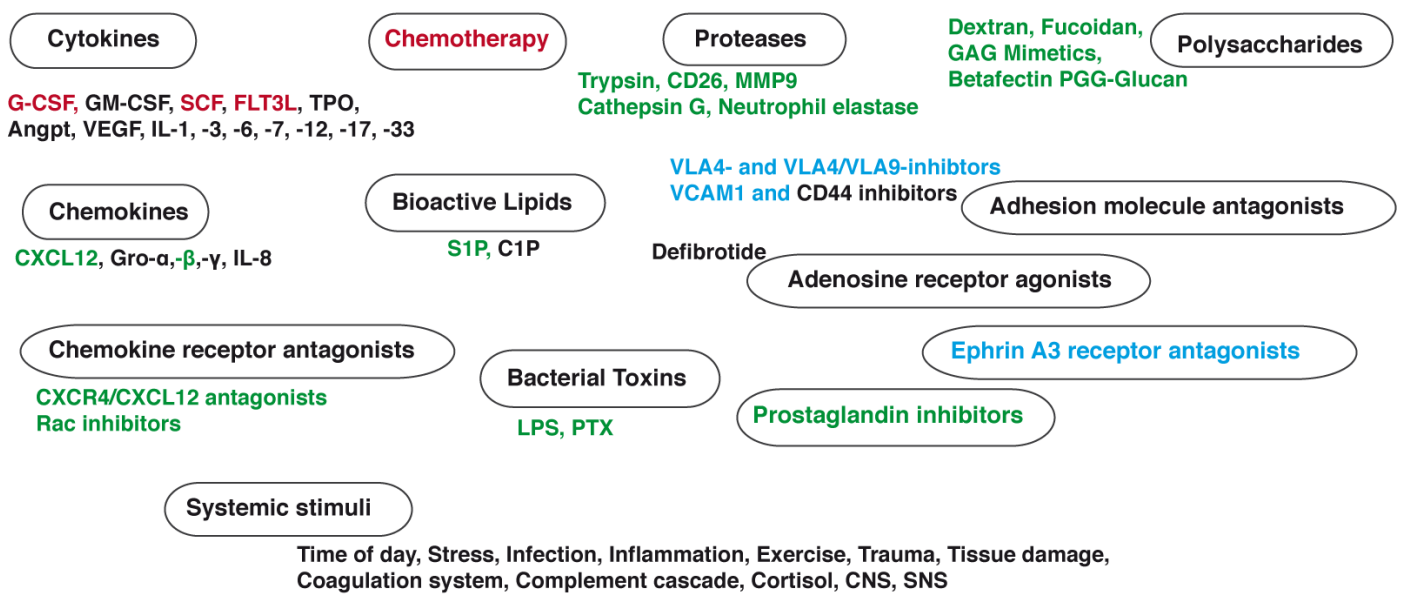

\section{Clinically Used:}

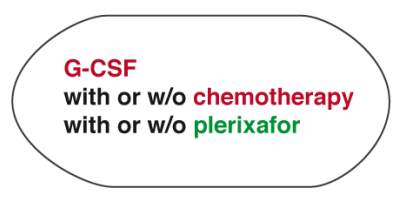

Figure 1. Mobilization stimuli. A wide variety of stimuli that lead to increased numbers of circulating hematopoietic stem cells (HSCs) have been identified, including but not limited to growth factors (cytokines ${ }^{17}$, granulocyte colony-stimulating factor [G-CSF] ${ }^{19,38}$, granulocytemacrophage colony-stimulating factor [GM-CSF] ${ }^{20}$, stem cell factor [SCF] ${ }^{18,39,40}$, FLT3 ligand [FLT3L] ${ }^{40-42}$, thrombopoietin [TPO] ${ }^{15,16,40}$, angiopoietin [Angpt] ${ }^{43,44}$, vascular endothelial growth factor [VEGF] ${ }^{43-45}$, and interleukins [ILs] $-1^{46},-3^{47,48},-6^{49},-7^{50},-12^{51},-17^{52}$, and $-33^{53,54}$, chemotherapy-induced myeloid rebound ${ }^{1,23,55}$, chemokines (CXCL12 and analogs ${ }^{27,56}$, Gro- $\alpha^{57},-\beta^{26,57-59}$, and $-\gamma^{57}$, and IL-8 $8^{24,25,60}$ ), chemokine receptor antagonists (CXCR4 antagonists ${ }^{61,62,63}$ and inhibitors of the intracellular mediator of CXCR4 signaling, the small Rho GTPase Rac1 ${ }^{64,65}$ ), bioactive lipids (sphingosine-1 phosphate $[\mathrm{S} 1 \mathrm{P}]^{66,67}$ and ceramide-1 phosphate $[\mathrm{C} 1 \mathrm{P}]^{66,67}$ ) and bacterial toxins ${ }^{36,68,69}$ (lipopolysaccharide $[\mathrm{LPS}]^{37,70}$ and pertussis toxin $[\mathrm{PTX}]^{71-74}$ ), proteases (trypsin ${ }^{75}$, matrix metalloprotease 9 [MMP9] ${ }^{58,76}$, CD26 $6^{77,78}$, cathepsin $\mathrm{G}^{79}$, and neutrophil elastase $^{79}$ ) and adenosine receptor agonists (defibrotide) ${ }^{80,81}$, inhibitors of adhesive cell interactions ${ }^{82}$ (VLA4 ${ }^{28,29,83}$ and VLA4/VLA9 ${ }^{84}$ inhibitors, VCAM1 ${ }^{85}$, and CD44 ${ }^{86,87}$ blockers) and ephrin A3 receptor antagonists ${ }^{88}$, polymeric sugar molecules (dextran ${ }^{89}$, fucoidan ${ }^{89,90}$, Betafectin PGG-Glucan ${ }^{91}$, and glycosaminoglycan [GAG] mimetics ${ }^{92}$ ), and prostaglandin inhibitors ${ }^{93}$. For the majority of the listed stimuli, a direct or indirect targeting of CXCR4 (green) or VLA4 (blue) signaling or both (red) has been documented. On the systemic level, the time of day ${ }^{10,11,94}$, stress $^{95,96}$ and exercise ${ }^{97-100}$, trauma and tissue damage ${ }^{101-103}$, infection ${ }^{104}$ and inflammation ${ }^{105,106}$, coagulation ${ }^{107-109}$ and complement ${ }^{110-113}$ cascade along with cortiso ${ }^{94,114}$ and the central ${ }^{114}$ as well as the sympathetic nervous system (SNS) ${ }^{115}$ have been shown to affect HSC egress out of the bone marrow (BM) into the peripheral blood. In sharp contrast to the diversity of mobilizing agents discovered and tested in preclinical models, only G-CSF alone (healthy donors) or in conjunction with chemotherapy and plerixafor (patients) is being used in the clinic. CNS, central nervous system. 
mobilization. While the function of homeostatically circulating HSCs remains enigmatic, pharmacologically induced HSC egress is increasingly used as the preferred strategy to generate grafts for HSC transplantation (HSCT), the only curative therapeutic option for many hematopoietic malignancies as well as non-malignant pathologies. HSCT requires the intravenous infusion of a minimum of $2 \times 10^{6} \mathrm{CD}^{4} 4^{+}$stem cells $/ \mathrm{kg}$ recipient body weight; however, a dose of $5 \times 10^{6} \mathrm{CD} 34^{+}$ cells $/ \mathrm{kg}$ is considered preferable for early, consistent, and long-term multilineage engraftment ${ }^{116-118}$. Each failure or delay to collect sufficient hematopoietic stem/progenitor cells (HSPCs) to proceed to transplantation extends the time of high-dose chemotherapy and increases the risk of disease progression in cancer patients.

The need to optimize mobilization regimens with regard to their stem cell yield, side effects and risk profile, cost-effectiveness, and availability for different groups of patients, as well as the need to better understand the communication between HSCs and their niche, continues to drive mobilization research. In this review, we discuss how deciphering the events induced by the most commonly used mobilizing agent, granulocyte colonystimulating factor (G-CSF), led to the development of new mobilization strategies. We highlight the most recent findings and how we envision the newly discovered mobilization approaches will impact mobilization in the clinic. Alternative applications for mobilization are also reviewed. Lastly, we identify open questions and controversies, prospective directions, and how recent technical advances can be implemented within mobilization research.

\section{Current mobilization regimens}

G-CSF-mobilized blood is the preferred graft source for virtually all autologous and an increasing majority of allogeneic HSCTs owing to its generally higher stem cell content, reduced rates of graft failure, and better overall survival as compared to the $\mathrm{BM}^{2,119,120}$. After 4-5 days of treatment with G-CSF, circulating HSPCs increase an average of 50-100-fold ${ }^{121,122}$ as a result of HSPC pool expansion followed by mobilization. The latter is achieved through targeting the two major pathways involved in stem cell retention: chemokine receptor CXCR4- and integrin VLA4-mediated signaling ${ }^{79,123,124}$. Attenuation of these pathways is achieved on the level of gene expression as well as through proteolytic cleavage ${ }^{79,123-127}$. While the role of specific proteases involved in the latter, such as neutrophil elastase, cathepsin G, and MMP9, remains controversial ${ }^{128,129}$, the cell surface protease dipeptidyl peptidase 4 (DPP-4, CD26), which cleaves and inactivates the CXCR4 ligand CXCL12, has indeed been shown to be essential for G-CSF-induced mobilization ${ }^{77,78}$.

Shortcomings of G-CSF such as the slow mode of action ${ }^{17,130}$, side effects, and contraindications ${ }^{131,132}$ as well as significant heterogeneity in the mobilization response ${ }^{121}$ explain the quest for alternative mobilizing agents ${ }^{133}$. Plerixafor (AMD3100), a small molecule bicyclam CXCR4 antagonist, is FDA approved for autologous stem cell mobilization in non-Hodgkin's lymphoma and multiple myeloma (MM) $)^{134,135}$. When combined with G-CSF, plerixafor increases $\mathrm{CD}^{+} 4^{+}$concentration 2-3-fold compared to
G-CSF alone ${ }^{134,135}$. However, a significant disadvantage of plerixafor is its cost, adding $\$ 25,567$ per patient compared to G-CSF alone ${ }^{136}$. Furthermore, up to $24 \%$ of patients undergoing autologous stem cell transplantation for lymphoma receiving plerixafor and G-CSF still fail to collect $\geq 2 \times 10^{6} \mathrm{CD}^{2} 4^{+}$cells $/ \mathrm{kg}$ in 4 days of apheresis ${ }^{134,135}$. A recent economic analysis determined that reducing apheresis by 1 day can potentially decrease medical costs by $\$ 6,600^{137}$. Thus improved/alternative mobilizing agents and strategies are needed.

The long-standing view has been that both HSPC expansion and mobilization are necessary for clinically relevant mobilization. In line with this view, mobilization with CXCR4 or VLA4 antagonists alone fails to achieve numbers that would allow their use without G-CSF, despite promising potential in preclinical models ${ }^{29,61,83,138-140}$. Very recent findings by our group and others challenge this notion and suggest that efficient recruitment of long-term, serially repopulating HSCs can be accomplished within minutes ${ }^{57,58}$. Indeed, CXCR4 or VLA4 blockade, when combined with the stimulation of a different chemokine receptor, CXCR2, results in extremely rapid and potent HSC mobilization in mice with a repopulating capacity similar or even superior to G-CSF-recruited HSCs ${ }^{57,58}$. These observations show that major changes in cellular composition or localization are not required for efficient mobilization. They further highlight the existence of different HSC species that, upon disruption of certain adhesive tethers, can egress from the BM very rapidly with kinetics that appear incompatible with a prior requirement for changes in gene expression.

The key role of the stromal compartment in G-CSF-induced mobilization has long been appreciated ${ }^{124,129,141}$. Following activation of their G-CSF receptor, BM monocytes/macrophages, the most prominent hematopoietic component of the BM stroma ${ }^{142-144}$, downregulate several retention molecules, including the major CXCR4 ligand, CXCL12, and several VLA4 ligands by nonhematopoietic stroma, resulting in HSPC egress ${ }^{143,145-147}$. Absence of the G-CSF receptor on monocytes/macrophages abrogates the G-CSF-induced mobilization response ${ }^{143}$, whereas the cytokine oncostatin $\mathrm{M}$ is thought to mediate communication between monocytes and non-hematopoietic stroma ${ }^{145,148}$. Interestingly, rapid mobilizing agents in general, and chemokines and chemokine receptor antagonists in particular, are assumed to act on hematopoietic cells directly. Our recent findings challenge this view and suggest a critical contribution of stromal (endothelial) CXCR2 targeting upon rapid HSC mobilization by the combination of the CXCR2 ligand truncated Gro-beta (tGro- $\beta$ ) and a VLA4 antagonis ${ }^{57}$. Since CXCR2 is absent from the HSPC surface ${ }^{25,26}$, CXCR2-expressing neutrophils have long been assumed to be the responding cell. Upon stimulation with CXCR2 agonists, neutrophils release proteases that cut adhesive interactions between HSPCs and their niche ${ }^{60,76,149,150}$. Yet CXCR2 within stroma was sufficient to induce mobilization with tGro- $\beta$ and a VLA4 antagonist ${ }^{57}$, pointing towards changes in endothelial layer permeability ${ }^{151}$ as well as crosstalk between endothelia and neutrophils as the "priming" events triggered by CXCR2 activation that boost VLA4 antagonist-induced HSPC egress (Figure 2). 


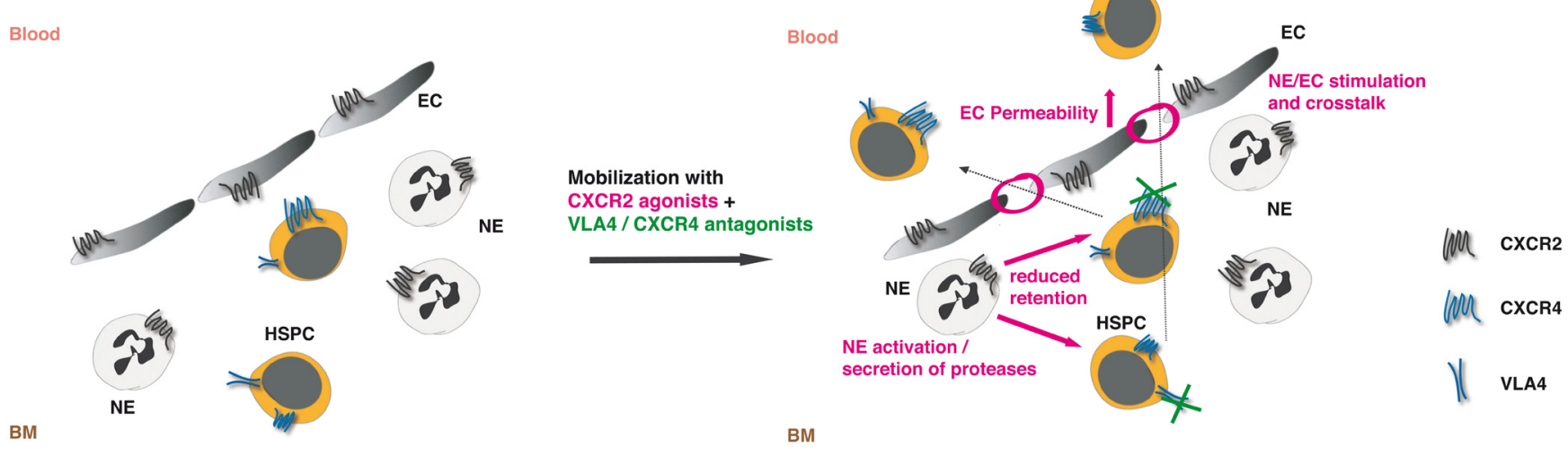

Figure 2. Mobilization priming effects of CXCR2 stimulation. Upon activation of the CXCR2 receptor on the surface of neutrophils (NE) and/or endothelial cells (EC), a reciprocal stimulation of the cells occurs that is critical for the subsequent boost of mobilization with a VLA4 or CXCR4 antagonist. Augmented mobilization appears to be a result of increased permeability of the endothelial layer together with other cell contact mediated or soluble factors derived from CXCR2-stimulated cells that reduce hematopoietic stem/progenitor cell (HSPC) retention. Additional inhibition of the VLA4 or CXCR4 receptor results in efficient targeting of the very primitive, serially repopulating HSPCs retained in the bone marrow (BM) primarily via VLA4 or CXCR4 signaling, respectively. The rapid kinetics of CXCR2 agonist + VLA4 or CXCR4 antagonist-induced mobilization preclude major molecular or cellular changes prior to the BM egress and rather suggest a close proximity of the primitive HSPC fraction to the BM sinusoids.

\section{Development of alternative HSPC mobilization regimens and grafts}

As we continue to learn about the events and mechanisms regulating HSPC egress, we approach the ultimate goal of developing an "optimal" mobilization strategy to collect sufficient numbers of primitive stem cells with superior properties within a day or two. In contrast to the days when clinical observations determined the applicability of a mobilization approach, educated and targeted designs are becoming the basis for the clinical development of mobilizing agents. In addition to the quantity and fitness of the HSPCs, as reflected in their engraftment capacity, the immunogenic properties of the graft (i.e. the graftversus-host disease [GvHD] profile) are an important feature requiring optimization, potentially at the cost of stem cell numbers. For example, a substantially reduced incidence of GvHD is observed upon transplantation of CXCR4 antagonistmobilized grafts, possibly due to co-mobilization of a specific population of dendritic cells (DCs) with immunomodulatory properties, plasmacytoid DCs ${ }^{140,152,153}$. Along the same lines, grafts mobilized with pegylated G-CSF were superior to standard G-CSF in that they were associated with less GvHD ${ }^{154,155}$ while graft-versus-leukemia (GvL) effects were improved through mobilization of invariant natural killer $\mathrm{T}$ (iNKT) cells ${ }^{155}$. Susceptibility of the mobilized HSPCs to further molecular manipulation, e.g. using gene therapy, is another important criterion when defining the "optimal" mobilization strategy. Lastly, if proven to be suitable for mobilized HSPCs, recently described methods for ex vivo expansion of $\mathrm{HSCs}^{156}$ are expected to shift the emphasis on HSPC quality over quantity even further.

Studies with CXCR4 and VLA4 antagonists, tested in VLA4 and CXCR4 knockout mice, respectively, implied an independence between the two axes ${ }^{139,157,158}$. This suggests that subsets of HSPCs are being retained in the BM by either CXCR4 or VLA4. Combined with the knowledge of the complexity and multiplicity of events induced in the course of G-CSF mobilization $^{129,133}$, co-existence of these (and possibly other) functionally distinct HSPC populations suggests combinatorial mobilization approaches as the best alternatives to G-CSF. Thus, the small molecule Me6TREN reportedly inhibits CXCR4 and VLA4 signaling simultaneously, possibly through upregulation of the protease MMP9 ${ }^{159}$. However, given the controversy regarding the role of MMP9 for mobilization ${ }^{128}$, other approaches should be explored. In addition to cell-intrinsic HSPC retention pathways, disruption of endothelial layer integrity, along with the endothelial cell activation and subsequent crosstalk between endothelial and mature hematopoietic cells, should be included in designing "optimal" mobilization. Recent data suggest that Viagra (sildenafil citrate), a phosphodiesterase type 5 (PDE5) inhibitor which blocks the degradation of cyclic GMP in the smooth muscle cells lining blood vessels, resulting in vasodilation, can synergize with plerixafor to rapidly mobilize stem cells in mice ${ }^{160}$.

Various techniques for ex vivo graft manipulation (e.g. T cell depletion and CD34 enrichment ${ }^{161-164}$ ) have been developed that entail extended periods during which the HSPCs stay outside of their natural environment and therefore, unsurprisingly, exhibit reduced stem cell capacity ${ }^{165,166}$. From further in-depth analyses of differentially mobilized blood (see below), we expect to learn not only how to target specific HSPC populations but also how to mobilize HSPCs without a concurrent mobilization of mature cells, T-cells in particular. In general, a priori cell type-specific targeting remains challenging because of the high conservation of migratory and retention pathways between different hematopoietic cell types. Nevertheless, selective HSPC mobilization represents an intriguing goal that would help reduce additional graft manipulation. 


\section{Mobilization beyond stem cell collection Chemosensitization}

In addition to supplying HSPCs with the factors required for their normal development, the BM microenvironment is also a refuge for malignant cells, allowing them to escape cytotoxic therapies and cause disease relapse ${ }^{167,168}$. This provides a rationale for targeting the interactions between tumor cells and the BM, with the goal of sensitizing them to therapy. Pathways responsible for the anchorage and survival of malignant cells and resistance to chemotherapy largely overlap with those of normal HSPCs ${ }^{168,169}$. Accordingly, blockade of CXCR4 and VLA4 signaling and/or G-CSF was tested in conjunction with chemotherapy in pre-clinical models of acute myeloid leukemia $\left(\mathrm{AML}^{170-173}\right.$ ), acute ${ }^{174,175}$ and chronic $^{176}$ lymphoid leukemia, and $\mathrm{MM}^{177}$. Moreover, the FDA-approved CXCR4 antagonist plerixafor has been tested as a chemosensitizing agent alone and in combination with G-CSF in patients with relapsed AML ${ }^{178,179}$. While the mobilizing capacity varied substantially, an overall benefit from adding mobilizing agent(s) to chemotherapy has been reported, prolonging survival and decreasing tumor burden ${ }^{170,172,177,180}$ or even eradicating disease ${ }^{175}$. The benefits of this approach in AML and other hematologic malignancies, in spite of these preclinical as well as early clinical studies, remain both unclear and controversial.

\section{Conditioning}

As HSPCs are pharmacologically driven from the BM into circulation, the temporarily unoccupied spaces (niches) in theory become available to new cells, e.g. the HSPCs introduced into a mobilized recipient during transplantation. The utility of mobilization for non-cytotoxic and on-target conditioning prior to HSCT is supported by the fact that mobilized cells return to the BM after spending some time in peripheral circulation, as shown in studies of parabiotic mice ${ }^{181}$. Yet virtually all attempts at mobilization alone for conditioning of an adult host before HSCT have been unsuccessful (Karpova and Rettig, unpublished data). It is unclear whether the reason is that the cells introduced exogenously are inherently disadvantaged (less fit?) compared with endogenously circulating HSPCs or whether the mobilizing agent interferes with the repopulating capacity of the transplanted cells. An intriguing alternative explanation is that owing to targeting/recruitment of a specific population during the mobilization process, and by extension because of emptying of very specific niches, only HSPCs mobilized with the same mobilizing regimen are able to engraft $\mathrm{BM}$ niches that become available. Interestingly, since BM- or fetal liver-derived HSPCs have been used to engraft mobilized recipients (Karpova and Rettig, unpublished data), the possibility that a qualitative rather than quantitative approach might lead to successful, persistent engraftment is untested. Given recent reports of successful conditioning using antibody-drug conjugates targeting the pan leukocyte marker CD45 ${ }^{182}$ and the CD117-targeting antibodies $^{183-185}$, or a cocktail of monoclonal antibodies depleting CD47-expressing cells along with $\mathrm{T}$ cells, NK cells, and HSPCs ${ }^{186}$, mobilization-based conditioning may not be a promising approach in postnatal recipients. However, fetal HSPC mobilization with a VLA4 antagonist followed by in utero HSCT results in increased donor HSC homing to the fetal liver and enhanced long-term allogeneic engraftment in mice ${ }^{187}$.
Therefore, mobilization-based conditioning regimens might be applicable for in utero HSCT.

\section{Gene therapy}

Manipulating HSCs to correct mutations that cause inherited diseases of the hematopoietic system such as sickle cell anemia and beta-thalassemia represents a potential cure, with recent advances in gene therapeutic approaches (CRISPR-Cas9, TALEN, and ZFN) ${ }^{188-193}$ allowing sustainable correction of the genetic defects. Autologous HSCT is the method of choice in this setting, whereby instead of extracting HSCs for subsequent ex vivo manipulation, stem cells are mobilized into the circulation and subjected to gene therapy in situ ${ }^{194-196}$. As discussed above, HSC collection and ex vivo editing inevitably leads to a diminished stem cell capacity, which can be avoided by editing the cells in the peripheral blood. Proof of principle for mobilization-based gene therapy was reported following mobilization with G-CSF plus a CXCR4 antagonist, with sustained expression of the introduced transgene over a period of 5 months ${ }^{196}$. We believe this approach should be developed further, e.g. by using it in combination with mobilization strategies to preferentially recruit stem cells with superior repopulating capacity into the circulation. In addition, these cells may be more susceptible to therapeutic gene editing. Apart from its obvious therapeutic benefit, this approach might become useful for studying functional differences between HSCs that have been mobilized into the circulation and returned to the BM and HSCs that remain in the BM niche.

\section{Biology of the hematopoietic niche}

The discovery of compounds and pathways that enable HSPC displacement from the niche has provided important insights into the regulation of HSPC trafficking and maintenance. For example, detailed analysis of the mechanisms underlying G-CSF-induced mobilization was indispensable for establishing monocytes/macrophages as crucial components of the BM niche and understanding their crosstalk with the non-hematopoietic stroma $^{143,145-147}$. More recent studies demonstrated that bone marrow dendritic cells regulate endothelial cell function in part through CXCR2 signaling, resulting in HSPC mobilization and loss of bone marrow macrophages ${ }^{151}$. Similarly, studies with the CXCR2 ligand tGro- $\beta$ disclosed the role of another mature leukocyte population, neutrophils, in HSPC trafficking ${ }^{57,58,76}$. Together with the observation that the circadian release of HSPCs into the circulation is synchronized by daily return of aged neutrophils from the circulation into the $\mathrm{BM}^{197}$, these findings implicate neutrophils as critical mediators of HSPC localization at steady state and upon enforced egress. On the molecular level, the recognition that all physiological, pathological, and pharmacological mobilization stimuli described to date interfere with VLA4 or CXCR4 signaling or both (Figure 1) highlights the key roles of these two pathways in HSPC trafficking.

\section{Open questions and future directions} Homeostatic HSPC trafficking

The physiological function and regulation of daily HSPC egress remain elusive. We know that, similar to their mature counterparts, the release of HSPCs from the BM follows a circadian 
rhythm ${ }^{11,94,198}$, with sympathetic nervous system-derived adrenergic signals acting through beta(3)-adrenergic receptors on BM stroma to downregulate CXCL12 signaling (and therefore retention $\left.{ }^{10,11}\right)$. While we understand the purpose of migration of more differentiated hematopoietic cells out of the BM to undergo maturation, encounter antigens, proliferate, etc., the role(s) of HSPCs found in blood and other peripheral tissues is speculative. Exchange between different parts of the hematopoietic system has been suggested to be mediated by homeostatic HSPC migration ${ }^{7,133}$ and is supported by observations from parabiotic $^{9,199,200}$ as well as partially irradiated ${ }^{201,202}$ mice. An alternative explanation implies a possible immune surveillance function of HSPCs that have also been found in the lymphoid system $^{203}$ and non-hematopoietic tissues with crucial immune functions such as the intestine ${ }^{204}$. Furthermore, expression of MHC class II molecules, otherwise restricted to professional antigen-presenting cells, has been detected in HSPCs ${ }^{205,206}$.

\section{Prediction of HSPC mobilization success and failure}

With regard to inadequate HSPC mobilization, one must distinguish between disease- and/or treatment-associated failure and failure of G-CSF mobilization in healthy donors. Of note, less than $1 \%$ of "healthy allogeneic donors" fail to collect an optimal $\left(5 \times 10^{6} \mathrm{CD} 34 / \mathrm{kg}\right)$ or minimal $\left(2 \times 10^{6} \mathrm{CD} 34 / \mathrm{kg}\right)$ amount of $\mathrm{CD}_{3} 4^{+}$cells after a standard 4-5-day regimen of G-CSF mobilization $^{133}$. This relatively uncommon event may represent the extreme heterogeneity of HSPC mobilization seen among the general population with no known medical conditions or prior exposure to chemotherapy or radiation. Thus, CD34 counts between 5 and 500 cells per $\mu$ l blood have been reported ${ }^{121}$. The general consensus, derived from studies of poor- and wellmobilizing mouse strains $s^{207,208}$, as well as repetitive mobilization of healthy donors ${ }^{121,209}$, is that genetic factors determine the mobilization response in healthy individuals. However, single nucleotide polymorphisms in any of the obvious candidate genes (including CXCL12 ${ }^{210}$, VCAM1 $1^{211,212}$, and CD44 ${ }^{212,213}$ ) do not correlate with mobilization efficacy in response to G-CSF or plerixafor in larger population studies ${ }^{133,214,215}$. Knowledge of high or low HSPC mobilization potential could be translated into donor screening prior to mobilization to help predict response and potentially to guide the best mobilization strategy.

The probability of mobilization failure in patients directly correlates with the amount and extent of prior cytotoxic exposure $^{216-218}$. Other clinical and demographic features of normal donors and patients undergoing autologous stem cell mobilization that predict poor mobilization include age ${ }^{217,219}$, resting platelet $\operatorname{counts}^{217,220}$, and a history of diabetes mellitus ${ }^{221}$. Failure rates have decreased since the CXCR4 antagonist plerixafor was approved for the mobilization of HSPCs for MM and nonHodgkin lymphoma patients when given in conjunction with G-CSF ${ }^{133-135}$. However, given that the diminished mobilization response results from the substantially reduced HSPC pool in these patients ${ }^{222}$, approaches that both potently expand HSPCs and induce their egress into the circulation are needed. We recently reported that the administration of CXCR4 antagonists to mice by subcutaneous continuous infusion for 1-4 weeks induces a robust mobilization response that significantly exceeds the mobilization achieved with bolus drug injections and was 25-50-fold greater than a 5-day course of G-CSF ${ }^{158}$. Moreover, continuous infusion of CXCR4 inhibitors leads to a two- to four-fold expansion of the HSPC pool in the bone marrow that exhibits a distinct repopulating advantage when tested in serial competitive transplantation experiments. Similarly, others have shown that the FMS-like tyrosine kinase 3 ligand (Flt3L) stimulates the expansion and mobilization of HSPCs in animals and humans ${ }^{223-225}$.

\section{Profiling of differentially mobilized blood}

Gene expression profiling of the HSPC populations mobilized with different agents has been performed, mostly using microarrays ${ }^{57,226}$. Not unexpectedly, increased relative expression of genes involved in lymphoid development were detected in grafts mobilized with a CXCR4 antagonist alone and in conjunction with G-CSF as compared to G-CSF alone ${ }^{226}$. A closer similarity between BM-resident and CXCR4 antagonistmobilized HPSCs as compared to BM-resident versus G-CSFmobilized HSPCs had been proposed to be due to the fast kinetics of CXCR4 antagonist-induced mobilization. However, the opposite was detected when comparing the three, with BMresident HSPCs showing a profile much closer to that of G-CSF-mobilized HSPCs ${ }^{57}$. It would appear from these studies that CXCR4 disruption recruits a specific rather than representative fraction of the BM HSPCs. By contrast, VLA4 antagonist + tGro- $\beta$-mobilized HSPCs have a profile very similar to that of BM-resident as well as G-CSF-mobilized HSPCs, indicating that rapid kinetics of mobilization can indeed be associated with an HSPC profile closely related to BM-resident $\mathrm{HSPC}^{57}$.

Single cell RNA sequencing (scRNA-seq) is currently revolutionizing the field of hematopoietic cancer research by defining the heterogeneity of malignant cells and the supporting network of non-malignant cells ${ }^{227-230}$. Naturally, scRNA-seq analysis and comparison of differentially mobilized HSPCs will provide key insights and may strengthen the notion that they are comprised of different HSPC subsets rather than representing a homogenous population with an overall altered expression profile depending on the agent used. Moreover, we anticipate that concurrent analysis of peripheral blood and BM HSPC compartments will shed new light on the unique identity and specific origin of mobilized cells that respond to specific mobilizing agents. In general, single cell characterization of mobilized blood/HSPCs is expected to be particularly informative with rapid-mobilizing agents, where the kinetics of the cell recruitment would not allow for major changes of the cell identity or localization prior to BM egress.

Interestingly, despite the more elaborate isolation process for non-hematopoietic as opposed to hematopoietic cells, a detailed characterization of the stromal populations using single cell approaches has been published already ${ }^{231-233}$. However, the contribution of the newly identified populations to HSPC retention remains unexplored. Ultimately, simultaneous analysis of stroma and HSPCs based on their proximity using spatial transcriptomics promises to reveal potentially unique relationships between certain stromal and hematopoietic cell types and thereby define the biological roles of the long-argued diversity within the hematopoietic niche. 


\section{Summary}

Pharmacologically induced egress of HSPCs from the BM has become an indispensable tool in HSCT with all autologous and over $80 \%$ of allogeneic transplants performed with mobilized blood. Mechanistic insights gained from studying the complex chain of events induced during mobilization with G-CSF have paved the way for the rational design of alternative mobilization approaches without the inherent shortcomings of G-CSF such as slow mode of action and side effects. Similar to the recruitment of healthy HSPCs into the circulation, targeting of various BM retention pathways has been explored as a means to sensitize leukemic cells and thereby improve the efficacy of chemotherapy. Moreover, mobilization of HSPCs as a non-cytotoxic conditioning strategy as well as for gene therapy represents two other applications of mobilization beyond mere collection of a stem cell graft. Understanding the physiological function of homeostatic HSPC trafficking and identifying the genetic determinants of mobilization efficiency, along with characterizing the differentially mobilized HSPC populations on a single cell level, represent some of the directions of future mobilization research.

\section{Acknowledgements}

We kindly thank Joel Eissenberg (St Louis University School of Medicine) and Elisa Donato (German Cancer Research Center [DKFZ] and DKFZ-ZMBH Alliance) for critical revision of the manuscript, helpful comments, and discussion. DK is a past scholar of the German Academic Exchange Service (postdoctoral fellowship ID: 57054578, 2014-2016).
1. Richman CM, Weiner RS, Yankee RA: Increase in circulating stem cells following chemotherapy in man. Blood. 1976; 47(6): 1031-9. PubMed Abstract

2. Henig I, Zuckerman T: Hematopoietic stem cell transplantation-50 years of evolution and future perspectives. Rambam Maimonides Med J. 2014; 5(4): e0028.

PubMed Abstract | Publisher Full Text | Free Full Text

3. Burns CE, Zon LI: Homing sweet homing: odyssey of hematopoietic stem cells Immunity. 2006; 25(6): 859-62.

PubMed Abstract | Publisher Full Text

4. Medvinsky A, Rybtsov S, Taoudi S: Embryonic origin of the adult hematopoietic system: advances and questions. Development. 2011; 138(6): 1017-31. PubMed Abstract | Publisher Full Text

5. Lo Celso C, Scadden DT: The haematopoietic stem cell niche at a glance. J Cell Sci. 2011; 124(Pt 21): 3529-35.

PubMed Abstract | Publisher Full Text | Free Full Text

6. Schofield R: The relationship between the spleen colony-forming cell and the haemopoietic stem cell. Blood Cells. 1978; 4(1-2): 7-25. PubMed Abstract

7. Wright DE, Wagers AJ, Gulati AP, et al:: Physiological migration of hematopoietic stem and progenitor cells. Science. 2001; 294(5548): 1933-6. PubMed Abstract | Publisher Full Text

8. Goodman JW, Hodgson GS: Evidence for stem cells in the peripheral blood of mice. Blood. 1962; 19(6): 702-14.

PubMed Abstract | Publisher Full Tex

9. Abkowitz JL, Robinson AE, Kale S, et al.: Mobilization of hematopoietic stem cells during homeostasis and after cytokine exposure. Blood. 2003; 102(4): 1249-53.

PubMed Abstract | Publisher Full Text

10. Méndez-Ferrer S, Chow A, Merad M, et al.: Circadian rhythms influence hematopoietic stem cells. Curr Opin Hematol. 2009; 16(4): 235-42. PubMed Abstract | Publisher Full Text | Free Full Text

11. F Méndez-Ferrer S, Lucas D, Battista M, et al:: Haematopoietic stem cell release is regulated by circadian oscillations. Nature. 2008; 452(7186): 442-7. PubMed Abstract | Publisher Full Text | F1000 Recommendation

12. F Scheiermann $C$, Kunisaki $Y$, Lucas $D$, et al:: Adrenergic nerves govern circadian leukocyte recruitment to tissues. Immunity. 2012; 37(2): 290-301. PubMed Abstract | Publisher Full Text | Free Full Text | F1000 Recommendation

13. Briddell RA, Hartley CA, Smith KA, et al:: Recombinant rat stem cell factor synergizes with recombinant human granulocyte colony-stimulating factor in vivo in mice to mobilize peripheral blood progenitor cells that have enhanced repopulating potential. Blood. 1993; 82(6): 1720-3. PubMed Abstract

14. McNiece IK, Briddell RA, Yan XQ, et al:: The role of stem cell factor in mobilization of peripheral blood progenitor cells. Leuk Lymphoma. 1994; 15(56): 405-9.

PubMed Abstract | Publisher Full Text

15. Vadhan-Raj S, Murray LJ, Bueso-Ramos C, et al:: Stimulation of megakaryocyte and platelet production by a single dose of recombinant human thrombopoietin in patients with cancer. Ann Intern Med. 1997; 126(9): 673-81. PubMed Abstract | Publisher Full Text
16. Murray LJ, Luens KM, Estrada MF, et al:: Thrombopoietin mobilizes CD34+ cell subsets into peripheral blood and expands multilineage progenitors in bone marrow of cancer patients with normal hematopoiesis. Exp Hematol. 1998; 26(3): 207-16.

PubMed Abstract

17. Nervi B, Link DC, Dipersio JF: Cytokines and hematopoietic stem cell mobilization. J Cell Biochem. 2006; 99(3): 690-705. PubMed Abstract | Publisher Full Text

18. Morstyn $\mathrm{G}$, Brown $\mathrm{S}$, Gordon $\mathrm{M}$, et al: Stem cell factor is a potent synergistic factor in hematopoiesis. Oncology. 1994; 51(2): 205-14. PubMed Abstract | Publisher Full Text

19. Matsunaga T, Sakamaki S, Kohgo Y, et al.: Recombinant human granulocyte colony-stimulating factor can mobilize sufficient amounts of peripheral blood stem cells in healthy volunteers for allogeneic transplantation. Bone Marrow Transplant. 1993; 11(2): 103-8. PubMed Abstract | Publisher Full Text

20. Mayer P, Lam C, Obenaus H, et al.: Recombinant human GM-CSF induces leukocytosis and activates peripheral blood polymorphonuclear neutrophils in nonhuman primates. Blood. 1987; 70(1): 206-13.

PubMed Abstract | Publisher Full Text

21. To LB, Haylock DN, Kimber RJ, et al.: High levels of circulating haemopoietic stem cells in very early remission from acute non-lymphoblastic leukaemia and their collection and cryopreservation. Br J Haematol. 1984: 58(3): 399-410. PubMed Abstract | Publisher Full Text

22. Stiff PJ, Murgo AJ, Wittes RE, et al:: Quantification of the peripheral blood colony forming unit-culture rise following chemotherapy. Could leukocytaphereses replace bone marrow for autologous transplantation? Transfusion. 1983; 23(6): 500-3.

PubMed Abstract | Publisher Full Text

23. To LB, Davy ML, Haylock DN, et al.: Autotransplantation using peripheral blood stem cells mobilized by cyclophosphamide. Bone Marrow Transplant. 1989; 4(5): 595-6. PubMed Abstract

24. Laterveer L, Lindley IJ, Heemskerk DP, et al:: Rapid mobilization of hematopoietic progenitor cells in rhesus monkeys by a single intravenous injection of interleukin-8. Blood. 1996; 87(2): 781-8. PubMed Abstract | Publisher Full Text

25. Laterveer L, Lindley IJ, Hamilton MS, et al.: Interleukin-8 induces rapid mobilization of hematopoietic stem cells with radioprotective capacity and long-term myelolymphoid repopulating ability. Blood. 1995; 85(8): 2269-75. PubMed Abstract | Publisher Full Text

26. Fukuda S, Bian H, King AG, et al:: The chemokine GRObeta mobilizes early hematopoietic stem cells characterized by enhanced homing and engraftment. Blood. 2007; 110(3): 860-9.

PubMed Abstract | Publisher Full Text | Free Full Text

27. Pelus LM, Bian H, Fukuda S, et al:: The CXCR4 agonist peptide, CTCE-0021, rapidly mobilizes polymorphonuclear neutrophils and hematopoietic progenitor cells into peripheral blood and synergizes with granulocyte colonystimulating factor. Exp Hematol. 2005; 33(3): 295-307. PubMed Abstract | Publisher Full Text

28. Bonig $\mathrm{H}$, Watts $\mathrm{KL}$, Chang $\mathrm{KH}$, et al:: Concurrent blockade of alpha4-integrin and CXCR4 in hematopoietic stem/progenitor cell mobilization. Stem Cells. 2009; 
27(4): 836-7

PubMed Abstract | Publisher Full Text | Free Full Text

29. Ramirez P, Rettig MP, Uy GL, et al.: BIO5192, a small molecule inhibitor of VLA-4, mobilizes hematopoietic stem and progenitor cells. Blood. 2009; 114(7): $1340-3$.

PubMed Abstract | Publisher Full Text | Free Full Text

30. Papayannopoulou T, Nakamoto B: Peripheralization of hemopoietic progenitors in primates treated with anti-VLA4 integrin. Proc Natl Acad Sci U S A. 1993; 90(20): 9374-8.

PubMed Abstract | Publisher Full Text | Free Full Text

31. Craddock CF, Nakamoto B, Andrews RG, et al.: Antibodies to VLA4 integrin mobilize long-term repopulating cells and augment cytokine-induced mobilization in primates and mice. Blood. 1997; 90(12): 4779-88. PubMed Abstract

32. Juarez JG, Harun N, Thien M, et al:: Sphingosine-1-phosphate facilitates trafficking of hematopoietic stem cells and their mobilization by CXCR4 antagonists in mice. Blood. 2012; 119(3): 707-16. PubMed Abstract | Publisher Full Text

33. F Ogle ME, Olingy CE, Awojoodu AO, et al:: Sphingosine-1-Phosphate Receptor-3 Supports Hematopoietic Stem and Progenitor Cell Residence Within the Bone Marrow Niche. Stem Cells. 2017; 35(4): 1040-52. PubMed Abstract | Publisher Full Text | Free Full Text | F1000 Recommendation

34. Zaldivar F, Eliakim A, Radom-Aizik S, et al:: The effect of brief exercise on circulating $\mathrm{CD}_{34}{ }^{+}$stem cells in early and late pubertal boys. Pediatr Res. 2007 61(4): 491-5. PubMed Abstract | Publisher Full Text

35. Barrett AJ, Longhurst $P$, Sneath $P$, et al: Mobilization of CFU-C by exercise and ACTH induced stress in man. Exp Hematol. 1978; 6(7): 590-4. PubMed Abstract

36. Cline MJ, Golde DW: Mobilization of hematopoietic stem cells (CFU-C) into the peripheral blood of man by endotoxin. Exp Hematol. 1977; 5(3): 186-90. PubMed Abstract

37. Benner R, Rijnbeek AM, Molendijk W, et al:: Genetic control of lipopolysaccharide-induced mobilization of CFUs. Dissociation between early and delayed mobilization of CFUs in complement C5-deficient mice and LPS non-responder mice. Cell Tissue Kinet. 1981; 14(2): 143-51.

PubMed Abstract | Publisher Full Text

38. Welte K, Bonilla MA, Gillio AP, et al.: Recombinant human granulocyte colony-stimulating factor. Effects on hematopoiesis in normal and cyclophosphamide-treated primates. J Exp Med. 1987; 165(4): 941-8. PubMed Abstract | Publisher Full Text | Free Full Text

39. Nakamura $Y$, Tajima F, Ishiga $\mathrm{K}$, et al:: Soluble c-kit receptor mobilizes hematopoietic stem cells to peripheral blood in mice. Exp Hematol. 2004; 32(4): 390-6.

PubMed Abstract | Publisher Full Text

40. Luens KM, Travis MA, Chen BP, et al:: Thrombopoietin, kit ligand, and flk2/ flt3 ligand together induce increased numbers of primitive hematopoietic progenitors from human CD34+Thy-1+Lin cells with preserved ability to engraft SCID-hu bone. Blood. 1998; 91(4): 1206-15.

PubMed Abstract | Publisher Full Tex

41. He S, Chu J, Vasu S, et al.: FLT3L and plerixafor combination increases hematopoietic stem cell mobilization and leads to improved transplantation outcome. Biol Blood Marrow Transplant. 2014; 20(3): 309-13. PubMed Abstract | Publisher Full Text | Free Full Text

42. Urdziková L, Likavčanová-Mašínová $\mathrm{K}$, Vaněček $\mathrm{V}$, et al.: Flt3 ligand synergizes with granulocyte-colony-stimulating factor in bone marrow mobilization to improve functional outcome after spinal cord injury in the rat. Cytotherapy. 2011; 13(9): 1090-104. PubMed Abstract | Publisher Full Text

43. Hattori K, Dias S, Heissig B, et al:: Vascular endothelial growth factor and angiopoietin-1 stimulate postnatal hematopoiesis by recruitment of vasculogenic and hematopoietic stem cells. J Exp Med. 2001; 193(9): 1005-14. PubMed Abstract | Publisher Full Text | Free Full Text

44. F Moore MA, Hattori K, Heissig B, et al:: Mobilization of endothelial and hematopoietic stem and progenitor cells by adenovector-mediated elevation of serum levels of SDF-1, VEGF, and angiopoietin-1. Ann NY Acad Sci. 2001; 938: $36-45$.

PubMed Abstract | Publisher Full Text | F1000 Recommendation

45. Rafii S, Heissig B, Hattori K: Efficient mobilization and recruitment of marrowderived endothelial and hematopoietic stem cells by adenoviral vectors expressing angiogenic factors. Gene Ther. 2002; 9(10): 631-41. PubMed Abstract | Publisher Full Text

46. Pruijt JF, van Kooyk Y, Figdor CG, et al.: Anti-LFA-1 blocking antibodies prevent mobilization of hematopoietic progenitor cells induced by interleukin-8. Blood. 1998; 91(11): 4099-105. PubMed Abstract

47. Down JD, Awwad M, Kurilla-Mahon B, et al.: Increases in autologous hematopoietic progenitors in the blood of baboons following irradiation and treatment with porcine stem cell factor and interleukin-3. Transplant Proc. 2000; 32(5): 1045-6. PubMed Abstract | Publisher Full Text

48. MacVittie TJ, Farese AM, Davis TA, et al.: Myelopoietin, a chimeric agonist of human interleukin 3 and granulocyte colony-stimulating factor receptors, mobilizes CD34+ cells that rapidly engraft lethally $x$-irradiated nonhuman primates. Exp Hematol. 1999; 27(10): 1557-68.

PubMed Abstract | Publisher Full Text

49. Pettengell R, Luft T, de Wynter E, et al.: Effects of interleukin- 6 on mobilization of primitive haemopoietic cells into the circulation. Br J Haematol. 1995; 89(2): 237-42.

PubMed Abstract | Publisher Full Text

50. Grzegorzewski KJ, Komschlies KL, Jacobsen SE, et al.: Mobilization of longterm reconstituting hematopoietic stem cells in mice by recombinant human interleukin 7. J Exp Med. 1995; 181(1): 369-74.

PubMed Abstract | Publisher Full Text | Free Full Text

51. Jackson JD, Yan $Y$, Brunda MJ, et al.: Interleukin-12 enhances peripheral hematopoiesis in vivo. Blood. 1995; 85(9): 2371-6.

PubMed Abstract | Publisher Full Text

52. Schwarzenberger $\mathrm{P}$, Huang $\mathrm{W}$, Oliver $\mathrm{P}$, et al:: II-17 mobilizes peripheral blood stem cells with short- and long-term repopulating ability in mice. $J$ Immunol. 2001: 167: 2081-6.

PubMed Abstract | Publisher Full Text

53. Kim J, Kim W, Le HT, et al:: IL-33-induced hematopoietic stem and progenitor cell mobilization depends upon CCR2. J Immunol. 2014; 193(7): 3792-802. PubMed Abstract | Publisher Full Text

54. F Alt C, Yuan S, Wu F, et al.: Long-Acting IL-33 Mobilizes High-Quality Hematopoietic Stem and Progenitor Cells More Efficiently Than Granulocyte Colony-Stimulating Factor or AMD3100. Biol Blood Marrow Transplant. 2019; 25(8): 1475-85.

PubMed Abstract | Publisher Full Text | F1000 Recommendation

55. Green DJ, Bensinger WI, Holmberg LA, et al.: Bendamustine, etoposide and dexamethasone to mobilize peripheral blood hematopoietic stem cells for autologous transplantation in patients with multiple myeloma. Bone Marrow Transplant. 2016; 51(10): 1330-6.

PubMed Abstract | Publisher Full Text | Free Full Text

56. Hattori K, Heissig B, Tashiro K, et al.: Plasma elevation of stromal cell-derived factor- 1 induces mobilization of mature and immature hematopoietic progenitor and stem cells. Blood. 2001; 97(11): 3354-60. PubMed Abstract | Publisher Full Text

57. Karpova D, Rettig MP, Ritchey J, et al.: Targeting VLA4 integrin and CXCR2 mobilizes serially repopulating hematopoietic stem cells. $J$ Clin Invest. 2019. 129(7): 2745-59.

PubMed Abstract | Publisher Full Text | Free Full Text

58. F Hoggatt J, Singh P, Tate TA, et al:: Rapid Mobilization Reveals a Highly Engraftable Hematopoietic Stem Cell. Cell. 2018; 172(1-2): 191-204.e10. PubMed Abstract | Publisher Full Text | Free Full Text | F1000 Recommendation

59. Pelus LM, Fukuda S: Peripheral blood stem cell mobilization: the CXCR2 ligand GRObeta rapidly mobilizes hematopoietic stem cells with enhanced engraftment properties. Exp Hematol. 2006; 34(8): 1010-20. PubMed Abstract | Publisher Full Text

60. Pruijt JF, Fibbe WE, Laterveer L, et al.: Prevention of interleukin-8-induced mobilization of hematopoietic progenitor cells in rhesus monkeys by inhibitory antibodies against the metalloproteinase gelatinase B (MMP-9). Proc Natl Acad Sci U S A. 1999; 96(19): 10863-8.

PubMed Abstract | Publisher Full Text | Free Full Text

61. Broxmeyer HE, Orschell CM, Clapp DW, et al:: Rapid mobilization of murine and human hematopoietic stem and progenitor cells with AMD3100, a CXCR4 antagonist. J Exp Med. 2005; 201(8): 1307-18. PubMed Abstract | Publisher Full Text | Free Full Text

62. Bonig $\mathrm{H}$, Chudziak D, Priestley $\mathrm{G}$, et al.: Insights into the biology of mobilized hematopoietic stem/progenitor cells through innovative treatment schedules of the CXCR4 antagonist AMD3100. Exp Hematol. 2009; 37(3): 402-15.e1. PubMed Abstract | Publisher Full Text | Free Full Text

63. Rettig MP, Ansstas G, DiPersio JF: Mobilization of hematopoietic stem and progenitor cells using inhibitors of CXCR4 and VLA-4. Leukemia. 2012; 26(1): $34-53$.

PubMed Abstract | Publisher Full Text | Free Full Text

64. Cancelas JA, Lee AW, Prabhakar $R$, et al:: Rac GTPases differentially integrate signals regulating hematopoietic stem cell localization. Nat Med. 2005; 11(8): 886-91.

PubMed Abstract | Publisher Full Text

65. Ghiaur G, Lee A, Bailey J, et al:: Inhibition of RhoA GTPase activity enhances hematopoietic stem and progenitor cell proliferation and engraftment. Blood. 2006; 108(6): 2087-94.

PubMed Abstract | Publisher Full Text

66. Karapetyan AV, Klyachkin YM, Selim S, et al:: Bioactive lipids and cationic antimicrobial peptides as new potential regulators for trafficking of bone marrow-derived stem cells in patients with acute myocardial infarction. Stem marrow-derived stem cells in patier

PubMed Abstract | Publisher Full Text | Free Full Text

67. Ratajczak MZ, Suszynska M, Borkowska S, et al:: The role of sphingosine-1 phosphate and ceramide-1 phosphate in trafficking of normal stem cells and cancer cells. Expert Opin Ther Targets. 2013; 18(1): 95-107. PubMed Abstract | Publisher Full Text | Free Full Text

68. Velders GA, Verzaal P, Van Os RP, et al:: Endotoxins serve as cofactors in cytokine induced mobilization of peripheral blood stem cells. Blood. 2000; 96. Reference Source 
69. F Velders $\mathrm{GA}$, van Os $\mathrm{R}$, Hagoort $\mathrm{H}$, et al: Reduced stem cell mobilization in mice receiving antibiotic modulation of the intestinal flora: Involvement of endotoxins as cofactors in mobilization. Blood. 2004; 103(1): 340-6. PubMed Abstract | Publisher Full Text | F1000 Recommendation

70. Molendijk WJ, Oudenaren A, Dijk H, et al:: Complement split product C5 mediates the lipopolysaccharide-induced mobilization of CFU-s and haemopoietic progenitor cells, but not the mobilization induced by proteolytic enzymes. Cell Tissue Kinet. 1986; 19(4): 407-17. PubMed Abstract | Publisher Full Text

71. Schneider OD, Weiss AA, Miller WE: Pertussis toxin signals through the TCR to initiate cross-desensitization of the chemokine receptor CXCR4. J Immunol. 2009; 182(9): 5730-9

PubMed Abstract | Publisher Full Text | Free Full Text

72. Papayannopoulou T, Priestley GV, Bonig H, et al:: The role of G-protein signaling in hematopoietic stem/progenitor cell mobilization. Blood. 2003; 101(12): 4739-47.

PubMed Abstract | Publisher Full Text

73. Bonig H, Priestley GV, Papayannopoulou T: Hierarchy of molecular-pathway usage in bone marrow homing and its shift by cytokines. Blood. 2006; 107(1): 79-86.

PubMed Abstract | Publisher Full Text | Free Full Text

74. Bonig H, Priestley GV, Nilsson LM, et al.: PTX-sensitive signals in bone marrow homing of fetal and adult hematopoietic progenitor cells. Blood. 2004; 104(8): 2299-306.

PubMed Abstract | Publisher Full Text

75. Fehér I, Gidáli J: Mobilizable stem cells: characteristics and replacement of the pool after exhaustion. Exp Hematol. 1982; 10(8): 661-7. PubMed Abstract

76. Pelus LM, Bian H, King AG, et al:: Neutrophil-derived MMP-9 mediates synergistic mobilization of hematopoietic stem and progenitor cells by the combination of G-CSF and the chemokines GRObeta/CXCL2 and GRObetaT/ CXCL2delta4. Blood. 2004; 103(1): 110-9.

PubMed Abstract | Publisher Full Text

77. Christopherson K, Cooper S, Hangoc G, et al: CD26 is essential for normal GCSF-induced progenitor cell mobilization as determined by $\mathrm{CD}^{-1-}$ mice. Exp Hematol. 2003: 31(11): 1126-34

PubMed Abstract | Publisher Full Text

78. Christopherson KW 2nd, Cooper S, Broxmeyer HE: Cell surface peptidase CD26/ DPPIV mediates G-CSF mobilization of mouse progenitor cells. Blood. 2003 ; 101(12): 4680-6.

PubMed Abstract | Publisher Full Text

79. Lévesque JP, Hendy J, Takamatsu Y, et al.: Disruption of the CXCR4/CXCL12 chemotactic interaction during hematopoietic stem cell mobilization induced by GCSF or cyclophosphamide. J Clin Invest. 2003; 111(2): 187-96. PubMed Abstract | Publisher Full Text | Free Full Text

80. Scalia R, Kochilas L, Campbell B, et al:: Effects of defibrotide on leukocyteendothelial cell interaction in the rat mesenteric vascular bed: role of P-selectin. Methods Find Exp Clin Pharmacol. 1996; 18(10): 669-76. PubMed Abstract

81. Carlo-Stella C, Di Nicola M, Magni M, et al: Defibrotide in combination with granulocyte colony-stimulating factor significantly enhances the mobilization of primitive and committed peripheral blood progenitor cells in mice. Cancer Res. 2002; 62(21): 6152-7. PubMed Abstract

82. Vermeulen M, Le Pesteur F, Gagnerault MC, et al:: Role of adhesion molecules in the homing and mobilization of murine hematopoietic stem and progenitor cells. Blood. 1998; 92(3): 894-900. PubMed Abstract | Publisher Full Text

83. Bonig $\mathrm{H}$, Wundes $\mathrm{A}$, Chang $\mathrm{KH}$, et al:: Increased numbers of circulating hematopoietic stem/progenitor cells are chronically maintained in patients treated with the CD49d blocking antibody natalizumab. Blood. 2008; 111(7): 3439-41.

PubMed Abstract | Publisher Full Text | Free Full Text

84. F Cao B, Zhang Z, Grassinger J, et al:: Therapeutic targeting and rapid mobilization of endosteal HSC using a small molecule integrin antagonist. Nat Commun. 2016; 7: 11007

PubMed Abstract | Publisher Full Text | Free Full Text | F1000 Recommendation

85. Kikuta T, Shimazaki C, Ashihara E, et al:: Mobilization of hematopoietic primitive and committed progenitor cells into blood in mice by anti-vascular adhesion molecule-1 antibody alone or in combination with granulocyte colonystimulating factor. Exp Hematol. 2000; 28(3): 311-7. PubMed Abstract | Publisher Full Text

86. Zoeller M: CD44v10 in hematopoiesis and stem cell mobilization. Leuk Lymphoma. 2000; 38(5-6): 463-80. PubMed Abstract | Publisher Full Tex

87. Rösel M, Khaldoyanidi S, Zawadzki V, et al:: Involvement of CD44 variant isoform v10 in progenitor cell adhesion and maturation. Exp Hematol. 1999; 27(4): 698-711.

PubMed Abstract | Publisher Full Text

88. Ting MJ, Day BW, Spanevello MD, et al.: Activation of ephrin A proteins influences hematopoietic stem cell adhesion and trafficking patterns. Exp Hematol. 2010; 38(11): 1087-98

PubMed Abstract | Publisher Full Text
89. Sweeney EA, Priestley GV, Nakamoto B, et al.: Mobilization of stem/progenitor cells by sulfated polysaccharides does not require selectin presence. Proc Nat/ Acad Sci U S A. 2000; 97(12): 6544-9.

PubMed Abstract | Publisher Full Text | Free Full Text

90. Sweeney EA, Lortat-Jacob H, Priestley GV, et al.: Sulfated polysaccharides increase plasma levels of SDF-1 in monkeys and mice: involvement in mobilization of stem/progenitor cells. Blood. 2002; 99(1): 44-51.

PubMed Abstract | Publisher Full Text

91. Patchen ML, Liang J, Vaudrain T, et al.: Mobilization of peripheral blood progenitor cells by Betafectin PGG-Glucan alone and in combination with granulocyte colony-stimulating factor. Stem Cells. 1998; 16(13): 208-17. PubMed Abstract | Publisher Full Text

92. Albanese P, Caruelle D, Frescaline G, et al.: Glycosaminoglycan mimeticsinduced mobilization of hematopoietic progenitors and stem cells into mouse peripheral blood: structure/function insights. Exp Hematol. 2009; 37(9): 1072-83. PubMed Abstract | Publisher Full Text

93. $\mathrm{F}$ Hoggatt J, Mohammad KS, Singh $\mathrm{P}$, et al.: Differential stem- and progenitorcell trafficking by prostaglandin $\mathrm{E}_{2}$. Nature. 2013; 495(7441): 365-9. PubMed Abstract | Publisher Full Text | Free Full Text | F1000 Recommendation

94. Stenzinger M, Karpova D, Unterrainer C, et al.: Hematopoietic-Extrinsic Cues Dictate Circadian Redistribution of Mature and Immature Hematopoietic Cells in Blood and Spleen. Cells. 2019; 8(9): pii: E1033. PubMed Abstract | Publisher Full Text | Free Full Text

95. F McKim DB, Yin W, Wang Y, et al.: Social Stress Mobilizes Hematopoietic Stem Cells to Establish Persistent Splenic Myelopoiesis. Cell Rep. 2018; 25(9): 2552-2562.e3.

PubMed Abstract | Publisher Full Text | Free Full Text | F1000 Recommendation

96. Machaliński B, Paczkowska E, Koziarska D, et al:: Mobilization of human hematopoietic stem/progenitor-enriched CD34+ cells into peripheral blood during stress related to ischemic stroke. Folia Histochem Cytobiol. 2006; 44(2): 97-101.

PubMed Abstract

97. Morici G, Zangla D, Santoro A, et al:: Supramaximal exercise mobilizes hematopoietic progenitors and reticulocytes in athletes. Am J Physiol Regul Integr Comp Physiol. 2005; 289(5): R1496-503. PubMed Abstract | Publisher Full Text

98. Sandri M, Adams V, Gielen S, et al.: Effects of exercise and ischemia on mobilization and functional activation of blood-derived progenitor cells in patients with ischemic syndromes: results of 3 randomized studies. Circulation. 2005; 111(25): 3391-9. PubMed Abstract | Publisher Full Text

99. F Emmons R, Niemiro GM, Owolabi O, et al.: Acute exercise mobilizes hematopoietic stem and progenitor cells and alters the mesenchymal stromal cell secretome. J Appl Physiol (1985). 2016; 120(6): 624-32. PubMed Abstract | Publisher Full Text | F1000 Recommendation

100. Kroepfl JM, Pekovits K, Stelzer I, et al.: Exercise increases the frequency of circulating hematopoietic progenitor cells, but reduces hematopoietic colonyforming capacity. Stem Cells Dev. 2012; 21(16): 2915-25. PubMed Abstract | Publisher Full Text

101. Grzelak I, Olszewski WL, Zaleska M, et al: Surgical trauma evokes a rise in the frequency of hematopoietic progenitor cells and cytokine levels in blood circulation. Eur Surg Res. 1998; 30(3): 198-204. PubMed Abstract | Publisher Full Text

102. F Kollet O, Dar A, Shivtiel S, et al.: Osteoclasts degrade endosteal components and promote mobilization of hematopoietic progenitor cells. Nat Med. 2006 12(6): 657-64

PubMed Abstract | Publisher Full Text | F1000 Recommendation

103. Hennemann B, Ickenstein G, Sauerbruch S, et al:: Mobilization of CD34+ hematopoietic cells, colony-forming cells and long-term culture-initiating cells into the peripheral blood of patients with an acute cerebral ischemic insult. Cytotherapy. 2008; 10(3): 303-11. PubMed Abstract | Publisher Full Text

104. Burberry A, Zeng MY, Ding L, et al.: Infection mobilizes hematopoietic stem cells through cooperative NOD-like receptor and Toll-like receptor signaling. Cell Host Microbe. 2014; 15(6): 779-91.

PubMed Abstract | Publisher Full Text | Free Full Text

105. F Ratajczak MZ, Adamiak M, Plonka M, et al:: Mobilization of hematopoietic stem cells as a result of innate immunity-mediated sterile inflammation in the bone marrow microenvironment-the involvement of extracellular nucleotides and purinergic signaling. Leukemia. 2018; 32(5): 1116-23. PubMed Abstract | Publisher Full Text | Free Full Text | F1000 Recommendation

106. F Adamiak M, Bujko K, Cymer M, et al:: Novel evidence that extracellular nucleotides and purinergic signaling induce innate immunity-mediated mobilization of hematopoietic stem/progenitor cells. Leukemia. 2018; 32(9): 1920-31.

PubMed Abstract | Publisher Full Text | Free Full Text | F1000 Recommendation

107. Tjwa M, Sidenius N, Moura R, et al.: Membrane-anchored uPAR regulates the proliferation, marrow pool size, engraftment, and mobilization of mouse hematopoietic stem/progenitor cells. J Clin Invest. 2009; 119(4): 1008-18. PubMed Abstract | Publisher Full Text | Free Full Text

108. Tjwa et al. Plasmin therapy enhances mobilization of HPCs after G-CSF. Blood. 2008;112:4048-4050. Blood. 2009; 113(21): 5368. Publisher Full Text 
109. Tjwa M, Janssens S, Carmeliet P: Plasmin therapy enhances mobilization of HPCs after G-CSF. Blood. 2008; 112(10): 4048-50. PubMed Abstract | Publisher Full Text | Free Full Text

110. Janowska-Wieczorek A, Marquez-Curtis LA, Shirvaikar N, et al.: The role of complement in the trafficking of hematopoietic stem/progenitor cells. Transfusion. 2012; 52(12): 2706-16. PubMed Abstract | Publisher Full Text | Free Full Text

111. Borkowska S, Suszynska M, Mierzejewska K, et al:: Novel evidence that crosstalk between the complement, coagulation and fibrinolysis proteolytic cascades is involved in mobilization of hematopoietic stem/progenitor cells (HSPCs). Leukemia. 2014; 28(11): 2148-54. PubMed Abstract | Publisher Full Text | Free Full Text

112. Borkowska S, Suszynska M, Wysoczynski M, et al.: Mobilization studies in C3-deficient mice unravel the involvement of a novel crosstalk between the coagulation and complement cascades in mobilization of hematopoietic stem progenitor cells. Leukemia. 2013; 27(9): 1928-30. PubMed Abstract | Publisher Full Text | Free Full Text

113. F Adamiak M, Abdelbaset-Ismail A, Suszynska M, et al:: Novel evidence that the mannan-binding lectin pathway of complement activation plays a pivotal role in triggering mobilization of hematopoietic stem/progenitor cells by activation of both the complement and coagulation cascades. Leukemia. 2017; 31(1) 262-5.

PubMed Abstract | Publisher Full Text | Free Full Text | F1000 Recommendation

114. F Pierce $\mathrm{H}$, Zhang D, Magnon C, et al:: Cholinergic Signals from the CNS Regulate G-CSF-Mediated HSC Mobilization from Bone Marrow via a Glucocorticoid Signaling Relay. Cell Stem Cell. 2017; 20(5): 648-658.e4. PubMed Abstract | Publisher Full Text | Free Full Text | F1000 Recommendation

115. F Katayama $\mathrm{Y}$, Battista M, Kao WM, et al:: Signals from the sympathetic nervous system regulate hematopoietic stem cell egress from bone marrow. Cell. 2006; 124(2): 407-21.

PubMed Abstract | Publisher Full Text | F1000 Recommendation

116. Weaver $\mathrm{CH}$, Hazelton $\mathrm{B}$, Birch $\mathrm{R}$, et al.: An analysis of engraftment kinetics as a function of the CD34 content of peripheral blood progenitor cell collections in 692 patients after the administration of myeloablative chemotherapy. Blood. 1995; 86(10): 3961-9.

PubMed Abstract | Publisher Full Text

117. Bensinger W, Appelbaum F, Rowley S, et al:: Factors that influence collection and engraftment of autologous peripheral-blood stem cells. J Clin Oncol. 1995; 13(10): 2547-55

PubMed Abstract | Publisher Full Text

118. Benedetti G, Patoia L, Giglietti A, et al:: Very large amounts of peripheral blood progenitor cells eliminate severe thrombocytopenia after high-dose melphalan in advanced breast cancer patients. Bone Marrow Transplant. 1999; 24(9): 971-9. PubMed Abstract | Publisher Full Text

119. Russell NH, Hunter A, Rogers S, et al:: Peripheral blood stem cells as an alternative to marrow for allogeneic transplantation. Lancet. 1993; 341(8858): 1482

PubMed Abstract | Publisher Full Text

120. van Besien $\mathrm{K}$, Shore T, Cushing M: Peripheral-blood versus bone marrow stem cells. N Engl J Med. 2013; 368(3): 287-8. PubMed Abstract | Publisher Full Text

121. Mueller MM, Bialleck H, Bomke B, et al.: Safety and efficacy of healthy voluntee stem cell mobilization with filgrastim G-CSF and mobilized stem cell apheresis: results of a prospective longitudinal 5-year follow-up study. Vox Sang. 2013; 104(1): 46-54.

PubMed Abstract | Publisher Full Text

122. Hölig K, Kramer M, Kroschinsky F, et al:: Safety and efficacy of hematopoietic stem cell collection from mobilized peripheral blood in unrelated volunteers: 12 years of single-center experience in 3928 donors. Blood. 2009; 114(18): $3757-63$.

PubMed Abstract | Publisher Full Text

123. Salvucci $O$, Jiang $K$, Gasperini $P$, et al:: MicroRNA126 contributes to granulocyte colony-stimulating factor-induced hematopoietic progenitor cell mobilization by reducing the expression of vascular cell adhesion molecule 1 . Haematologica. 2012; 97(6): 818-26. PubMed Abstract | Publisher Full Text | Free Full Text

124. Semerad CL, Christopher MJ, Liu F, et al.: G-CSF potently inhibits osteoblast activity and CXCL12 mRNA expression in the bone marrow. Blood. 2005; 106(9): $3020-7$.

PubMed Abstract | Publisher Full Text | Free Full Text

125. Winkler IG, Hendy J, Coughlin $P$, et al:: Serine protease inhibitors serpina1 and serpina 3 are down-regulated in bone marrow during hematopoietic progenito mobilization. J Exp Med. 2005; 201(7): 1077-88. PubMed Abstract | Publisher Full Text | Free Full Text

126. Lévesque JP, Hendy J, Takamatsu Y, et al.: Mobilization by either cyclophosphamide or granulocyte colony-stimulating factor transforms the bone marrow into a highly proteolytic environment. Exp Hematol. 2002; 30(5): $440-9$.

PubMed Abstract | Publisher Full Text

127. Lévesque JP, Hendy J, Winkler IG, et al.: Granulocyte colony-stimulating factor induces the release in the bone marrow of proteases that cleave c-KIT receptor (CD117) from the surface of hematopoietic progenitor cells. Exp Hematol. 2003; 31(2): 109-17.

PubMed Abstract | Publisher Full Tex
128. Levesque JP, Liu F, Simmons PJ, et al.: Characterization of hematopoietic progenitor mobilization in protease-deficient mice. Blood. 2004; 104(1): $65-72$

PubMed Abstract | Publisher Full Text

129. Greenbaum AM, Link DC: Mechanisms of G-CSF-mediated hematopoietic stem and progenitor mobilization. Leukemia. 2011; 25(2): 211-7.

PubMed Abstract | Publisher Full Text

130. Anderlini $P$, Przepiorka D, Huh $Y$, et al.: Duration of filgrastim mobilization and apheresis yield of $\mathrm{CD} 34^{+}$progenitor cells and lymphoid subsets in normal donors for allogeneic transplantation. Br J Haematol. 1996; 93(4): 940-2. PubMed Abstract | Publisher Full Text

131. Anderlini P, Przepiorka D, Champlin R, et al.: Biologic and clinical effects of granulocyte colony-stimulating factor in normal individuals. Blood. 1996; 88(8): 2819-25.

PubMed Abstract | Publisher Full Text

132. Anderlini $P$, Champlin RE: Biologic and molecular effects of granulocyte colony-stimulating factor in healthy individuals: recent findings and current challenges. Blood. 2008; 111(4): 1767-72.

PubMed Abstract | Publisher Full Text

133. Karpova D, Wiercinska E, Bönig H: Mobilisierung hämatopoietischer Stammzellen. Transfusionsmedizin. 2013; 3(3): 127-39. Publisher Full Text

134. DiPersio JF, Micallef IN, Stiff PJ, et al.: Phase III prospective randomized doubleblind placebo-controlled trial of plerixafor plus granulocyte colony-stimulating factor compared with placebo plus granulocyte colony-stimulating factor for autologous stem-cell mobilization and transplantation for patients with nonHodgkin's lymphoma. J Clin Oncol. 2009; 27(28): 4767-73. PubMed Abstract | Publisher Full Tex

135. DiPersio JF, Stadtmauer EA, Nademanee A, et al.: Plerixafor and G-CSF versus placebo and G-CSF to mobilize hematopoietic stem cells for autologous stem cell transplantation in patients with multiple myeloma. Blood. 2009; 113(23): 5720-6.

PubMed Abstract | Publisher Full Text

136. Kymes SM, Pusic I, Lambert DL, et al:: Economic evaluation of plerixafor for stem cell mobilization. Am J Manag Care. 2012; 18(1): 33-41. PubMed Abstract | Free Full Text

137. Hosing C, Smith V, Rhodes B, et al:: Assessing the charges associated with hematopoietic stem cell mobilization and remobilization in patients with lymphoma and multiple myeloma undergoing autologous hematopoietic peripheral blood stem cell transplantation. Transfusion. 2011; 51(6): 1300-13. PubMed Abstract | Publisher Full Tex

138. F Devine SM, Vij R, Rettig M, et al.: Rapid mobilization of functional dono hematopoietic cells without G-CSF using AMD3100, an antagonist of the CXCR4/SDF-1 interaction. Blood. 2008; 112(4): 990-8.

PubMed Abstract | Publisher Full Text | F1000 Recommendation

139. Karpova D, Dauber K, Spohn G, et al.: The novel CXCR4 antagonist POL5551 mobilizes hematopoietic stem and progenitor cells with greater efficiency than Plerixafor. Leukemia. 2013; 27(12): 2322-31. PubMed Abstract | Publisher Full Text | Free Full Text

140. Karpova D, Bräuninger S, Wiercinska E, et al:: Mobilization of hematopoietic stem cells with the novel CXCR4 antagonist POL6326 (balixafortide) in healthy volunteers-results of a dose escalation trial. J Transl Med. 2017; 15(1): 2 . PubMed Abstract | Publisher Full Text | Free Full Text

141. F Winkler IG, Pettit AR, Raggatt LJ, et al:: Hematopoietic stem cell mobilizing agents G-CSF, cyclophosphamide or AMD3100 have distinct mechanisms of action on bone marrow HSC niches and bone formation. Leukemia. 2012; 26(7): 1594-601.

PubMed Abstract | Publisher Full Text | F1000 Recommendation

142. F Chow A, Lucas D, Hidalgo A, et al:: Bone marrow CD169+ macrophages promote the retention of hematopoietic stem and progenitor cells in the mesenchymal stem cell niche. J Exp Med. 2011; 208(2): 261-71.

PubMed Abstract | Publisher Full Text | Free Full Text | F1000 Recommendation

143. F Christopher MJ, Rao M, Liu F, et al.: Expression of the G-CSF receptor in monocytic cells is sufficient to mediate hematopoietic progenitor mobilization by G-CSF in mice. J Exp Med. 2011; 208(2): 251-60.

PubMed Abstract | Publisher Full Text | Free Full Text | F1000 Recommendation

144. Liu F, Poursine-Laurent J, Link DC: Expression of the G-CSF receptor on hematopoietic progenitor cells is not required for their mobilization by G-CSF. Blood. 2000; 95(10): 3025-31. PubMed Abstract | Publisher Full Text

145. Albiero M, Poncina N, Ciciliot S, et al.: Bone Marrow Macrophages Contribute to Diabetic Stem Cell Mobilopathy by Producing Oncostatin M. Diabetes. 2015; 64(8): 2957-68. PubMed Abstract | Publisher Full Text

146. Winkler IG, Sims NA, Pettit AR, et al:: Bone marrow macrophages maintain hematopoietic stem cell (HSC) niches and their depletion mobilizes HSCs. Blood. 2010; 116(23): 4815-28. PubMed Abstract | Publisher Full Text

147. Barbier V, Winkler IG, Lévesque JP: Mobilization of hematopoietic stem cells by depleting bone marrow macrophages. Methods Mol Biol. 2012; 904: 117-38. PubMed Abstract | Publisher Full Text

148. Minehata K, Takeuchi M, Hirabayashi $\mathrm{Y}$, et al:: Oncostatin m maintains the hematopoietic microenvironment and retains hematopoietic progenitors in the 
bone marrow. Int J Hematol. 2006; 84(4): 319-27. PubMed Abstract | Publisher Full Text

149. Pruijt JF, Verzaal $P$, van Os R, et al:: Neutrophils are indispensable for hematopoietic stem cell mobilization induced by interleukin-8 in mice. Proc Natl Acad Sci U S A. 2002; 99(9): 6228-33.

PubMed Abstract | Publisher Full Text | Free Full Text

150. Fibbe WE, Pruijt JF, Velders GA, et al:: Biology of IL-8-induced stem cell mobilization. Ann NY Acad Sci. 1999; 872: 71-82. PubMed Abstract | Publisher Full Tex

151. F Zhang J, Supakorndej T, Krambs JR, et al:: Bone marrow dendritic cells regulate hematopoietic stem/progenitor cell trafficking. J Clin Invest. 2019; 129(7): 2920-31.

PubMed Abstract | Publisher Full Text | Free Full Text | F1000 Recommendation

152. Rettig MP, McFarland K, Ritchey J, et al.: Preferential Mobilization of CD34+ Plasmacytoid Dendritic Cell Precursors by Plerixafor. Blood. 2009; 114(22): 32. Publisher Full Text

153. Schroeder MA, Rettig MP, Lopez S, et al.: Mobilization of allogeneic peripheral blood stem cell donors with intravenous plerixafor mobilizes a unique graft. Blood. 2017; 129(19): 2680-92.

PubMed Abstract | Publisher Full Text | Free Full Text

154. Morris ES, MacDonald KP, Rowe V, et al.: Donor treatment with pegylated G-CSF augments the generation of IL-10-producing regulatory $T$ cells and promotes transplantation tolerance. Blood. 2004; 103(9): 3573-81. PubMed Abstract | Publisher Full Text

155. Banovic T, MacDonald KP, Markey KA, et al:: Donor treatment with a multipegylated G-CSF maximizes graft-versus-leukemia effects. Biol Blood Marrow Transplant. 2009; 15(1): 126-30. PubMed Abstract | Publisher Full Tex

156. F Wilkinson $\mathrm{AC}$, Ishida $\mathrm{R}$, Kikuchi $\mathrm{M}$, et al:: Long-term ex vivo haematopoieticstem-cell expansion allows nonconditioned transplantation. Nature. 2019; 571(7763): 117-21

PubMed Abstract | Publisher Full Text | F1000 Recommendation

157. F Christopher MJ, Liu F, Hilton MJ, et al:: Suppression of CXCL12 production by bone marrow osteoblasts is a common and critical pathway for cytokineinduced mobilization. Blood. 2009; 114(7): 1331-9. PubMed Abstract | Publisher Full Text | Free Full Text | F1000 Recommendation

158. Karpova D, Ritchey JK, Holt MS, et al:: Continuous blockade of CXCR4 results in dramatic mobilization and expansion of hematopoietic stem and progenitor cells. Blood. 2017; 129(21): 2939-49. PubMed Abstract | Publisher Full Text | Free Full Text

159. Zhang J, Ren X, Shi W, et al:: Small molecule Me6TREN mobilizes hematopoietic stem/progenitor cells by activating MMP-9 expression and disrupting SDF-1/CXCR4 axis. Blood. 2014; 123(3): 428-41. PubMed Abstract | Publisher Full Text

160. F Smith-Berdan S, Bercasio A, Rajendiran S, et al:: Viagra Enables Efficient, Single-Day Hematopoietic Stem Cell Mobilization. Stem Cell Reports. 2019; 13(5): 787-92. PubMed Abstract | Publisher Full Text | F1000 Recommendation

161. Handgretinger R: New approaches to graft engineering for haploidentical bone marrow transplantation. Semin Oncol. 2012; 39(6): 664-73. PubMed Abstract | Publisher Full Text

162. Handgretinger R: Negative depletion of CD3(+) and TcR $\alpha \beta(+) T$ cells. Curr Opin Hematol 2012; 19(6): 434-9.

PubMed Abstract | Publisher Full Tex

163. Bethge WA, Haegele M, Faul C, et al:: Haploidentical allogeneic hematopoietic cell transplantation in adults with reduced-intensity conditioning and CD3/ CD19 depletion: fast engraftment and low toxicity. Exp Hematol. 2006; 34(12): $1746-52$.

PubMed Abstract | Publisher Full Text

164. Spohn G, Wiercinska E, Karpova D, et al:: Automated CD34+ cell isolation of peripheral blood stem cell apheresis product. Cytotherapy. 2015; 17(10): 1465-71. PubMed Abstract | Publisher Full Text

165. F Kumar S, Geiger H: HSC Niche Biology and HSC Expansion Ex Vivo. Trends Mol Med. 2017; 23(9): 799-819.

PubMed Abstract | Publisher Full Text | Free Full Text | F1000 Recommendation

166. F Eaves CJ: Hematopoietic stem cells: concepts, definitions, and the new reality. Blood. 2015; 125(17): 2605-13.

PubMed Abstract | Publisher Full Text | Free Full Text | F1000 Recommendation

167. Lane SW, Scadden DT, Gilliland DG: The leukemic stem cell niche: current concepts and therapeutic opportunities. Blood. 2009; 114(6): 1150-7. PubMed Abstract | Publisher Full Text | Free Full Text

168. Schroeder MA, DiPersio JF: Mobilization of hematopoietic stem and leukemia cells. J Leukoc Biol. 2012; 91(1): 47-57. PubMed Abstract | Publisher Full Text

169. Konopleva $\mathrm{M}$, Tabe $\mathrm{Y}$, Zeng $\mathrm{Z}$, et al.: Therapeutic targeting of microenvironmental interactions in leukemia: mechanisms and approaches. Drug Resist Updat. 2009; 12(4-5): 103-13. PubMed Abstract | Publisher Full Text | Free Full Text

170. Nervi B, Ramirez P, Rettig MP, et al.: Chemosensitization of acute myeloid eukemia (AML) following mobilization by the CXCR4 antagonist AMD3100. Blood. 2009; 113(24): 6206-14.

PubMed Abstract | Publisher Full Text | Free Full Text
171. Nervi B, Holt M, Rettig MP, et al:: AMD3100 Mobilizes Acute Promyelocytic Leukemia Cells from the Bone Marrow into the Peripheral Blood and Sensitizes Leukemia Cells to Chemotherapy. ASH Annu Meet Abstr. 2005. Reference Source

172. F Zeng Z, Shi YX, Samudio IJ, et al:: Targeting the leukemia microenvironment by CXCR4 inhibition overcomes resistance to kinase inhibitors and chemotherapy in AML. Blood. 2009; 113(24): 6215-24.

PubMed Abstract | Publisher Full Text | Free Full Text | F1000 Recommendation

173. Matsunaga T, Takemoto N, Sato T, et al.: Interaction between leukemic-cell VLA4 and stromal fibronectin is a decisive factor for minimal residual disease of acute myelogenous leukemia. Nat Med. 2003; 9(9): 1158-65.

PubMed Abstract | Publisher Full Text

174. F Parameswaran R, Yu M, Lim M, et al:: Combination of drug therapy in acute ymphoblastic leukemia with a CXCR4 antagonist. Leukemia. 2011; 25(8): 1314-23.

PubMed Abstract | Publisher Full Text | Free Full Text | F1000 Recommendation

175. Hsieh YT, Gang EJ, Geng H, et al.: Integrin alpha4 blockade sensitizes drug resistant pre-B acute lymphoblastic leukemia to chemotherapy. Blood. 2013; 121(10): 1814-8.

PubMed Abstract | Publisher Full Text | Free Full Text

176. Burger M, Hartmann T, Krome M, et al:: Small peptide inhibitors of the CXCR4 chemokine receptor (CD184) antagonize the activation, migration, and antiapoptotic responses of CXCL12 in chronic lymphocytic leukemia B cells. Blood. 2005; 106(5): 1824-30.

PubMed Abstract | Publisher Full Text

177. Azab AK, Runnels JM, Pitsillides C, et al.: CXCR4 inhibitor AMD3100 disrupts the interaction of multiple myeloma cells with the bone marrow microenvironment and enhances their sensitivity to therapy. Blood. 2009; 113(18): 4341-51. PubMed Abstract | Publisher Full Text | Free Full Text

178. F Uy GL, Rettig MP, Motabi IH, et al.: A phase $1 / 2$ study of chemosensitization with the CXCR4 antagonist plerixafor in relapsed or refractory acute myeloid leukemia. Blood. 2012; 119(17): 3917-24.

PubMed Abstract | Publisher Full Text | Free Full Text | F1000 Recommendation

179. Uy GL, Rettig MP, Stone RM, et al:: A phase $1 / 2$ study of chemosensitization with plerixafor plus G-CSF in relapsed or refractory acute myeloid leukemia. Blood Cancer J. 2017; 7(3): e542.

PubMed Abstract | Publisher Full Text | Free Full Text

180. Beider K, Begin M, Abraham M, et al:: CXCR4 antagonist 4F-benzoyl-TN14003 inhibits leukemia and multiple myeloma tumor growth. Exp Hematol. 2011; 39(3): 282-92.

PubMed Abstract | Publisher Full Text

181. F Chen J, Larochelle A, Fricker S, et al: Mobilization as a preparative regimen for hematopoietic stem cell transplantation. Blood. 2006; 107(9): 3764-71. PubMed Abstract | Publisher Full Text | Free Full Text | F1000 Recommendation

182. F Palchaudhuri R, Saez B, Hoggatt J, et al.: Non-genotoxic conditioning for hematopoietic stem cell transplantation using a hematopoietic-cell-specific internalizing immunotoxin. Nat Biotechnol. 2016; 34(7): 738-45. PubMed Abstract | Publisher Full Text | Free Full Text | F1000 Recommendation

183. Pang WW, Czechowicz A, Poyser J, et al.: Anti-Human CD117 Antibodies Mediate Clearance of Myelodysplastic Syndrome Hematopoietic Stem Cells and Facilitate Establishment of Normal Hematopoiesis in Transplantation. Biol Blood Marrow Transplant. 2018; 24(3): S230-S231. Publisher Full Text

184. F Czechowicz A, Kraft D, Weissman IL, et al.: Efficient transplantation via antibody-based clearance of hematopoietic stem cell niches. Science. 2007; 318(5854): 1296-9.

PubMed Abstract | Publisher Full Text | Free Full Text | F1000 Recommendation

185. F Czechowicz A, Palchaudhuri R, Scheck A, et al: Selective hematopoietic stem cell ablation using CD117-antibody-drug-conjugates enables safe and effective transplantation with immunity preservation. Nat Commun. 2019; 10(1):

PubMed Abstract | Publisher Full Text | Free Full Text | F1000 Recommendation

186. F George BM, Kao KS, Kwon HS, et al:: Antibody Conditioning Enables MHCMismatched Hematopoietic Stem Cell Transplants and Organ Graft Tolerance. Cell Stem Cell. 2019; 25(2): 185-192.e3.

PublMed Abstract | Publisher Full Text | Free Full Text | F1000 Recommendation

187. Kim AG, Vrecenak JD, Boelig MM, et al.: Enhanced in utero allogeneic engraftment in mice after mobilizing fetal HSCs by $\alpha 4 \beta 1 / 7$ inhibition. Blood. 2016; 128(20): 2457-61.

PubMed Abstract | Publisher Full Text | Free Full Text

188. Byrne SM, Mali $P$, Church GM: Genome editing in human stem cells. Meth Enzymol. 2014; 546: 119-38.

PubMed Abstract | Publisher Full Text | Free Full Text

189. F Yu KR, Natanson H, Dunbar CE: Gene Editing of Human Hematopoietic Stem and Progenitor Cells: Promise and Potential Hurdles. Hum Gene Ther. 2016; 27(10): 729-40.

PubMed Abstract | Publisher Full Text | Free Full Text | F1000 Recommendation

190. F Bak RO, Dever DP, Porteus MH: CRISPR/Cas9 genome editing in human hematopoietic stem cells. Nat Protoc. 2018; 13(2): 358-76. PubMed Abstract | Publisher Full Text | Free Full Text | F1000 Recommendation

191. F Kuo CY, Long JD, Campo-Fernandez B, et al.: Site-Specific Gene Editing of 
Human Hematopoietic Stem Cells for X-Linked Hyper-IgM Syndrome. Cell Rep. 2018; 23(9): 2606-16

PubMed Abstract | Publisher Full Text | Free Full Text | F1000 Recommendation

192. F Cavazzana M, Bushman FD, Miccio A, et al:: Gene therapy targeting haematopoietic stem cells for inherited diseases: progress and challenges. Nat Rev Drug Discov. 2019; 18(6): 447-62.

PubMed Abstract | Publisher Full Text | F1000 Recommendation

193. F Naldini L: Genetic engineering of hematopoiesis: current stage of clinical translation and future perspectives. EMBO Mol Med. 2019; 11(3): pii: e9958. PubMed Abstract | Publisher Full Text | Free Full Text | F1000 Recommendation

194. Yannaki E, Karponi G, Zervou F, et al:: Hematopoietic stem cell mobilization for gene therapy: superior mobilization by the combination of granulocyte-colony stimulating factor plus plerixafor in patients with $\beta$-thalassemia major. Hum Gene Ther 2013; 24(10): 852-60.

PubMed Abstract | Publisher Full Text | Free Full Text

195. Yannaki E, Papayannopoulou T, Jonlin E, et al.: Hematopoietic stem cell mobilization for gene therapy of adult patients with severe $\beta$-thalassemia: results of clinical trials using G-CSF or plerixafor in splenectomized and nonsplenectomized subjects. Mol Ther. 2012; 20(1): 230-8. PubMed Abstract | Publisher Full Text | Free Full Text

196. F Richter M, Saydaminova K, Yumul R, et al.: In vivo transduction of primitive mobilized hematopoietic stem cells after intravenous injection of integrating adenovirus vectors. Blood. 2016; 128(18): 2206-17.

PubMed Abstract | Publisher Full Text | Free Full Text | F1000 Recommendation

197. Casanova-Acebes M, Pitaval C, Weiss LA, et al:: Rhythmic modulation of the hematopoietic niche through neutrophil clearance. Cell. 2013; 153(5): 1025-35. PubMed Abstract | Publisher Full Text | Free Full Text

198. F Lucas D, Battista M, Shi PA, et al:: Mobilized hematopoietic stem cell yield depends on species-specific circadian timing. Cell Stem Cell. 2008; 3(4): 364-6. PubMed Abstract | Publisher Full Text | Free Full Text | F1000 Recommendation

199. Harris JE, Ford CE, Barnes DW, et al:: Evidence from Parabiosis for an Afferent Stream of Cells. Nature. 1964; 201: 886-7. PubMed Abstract | Publisher Full Text

200. McBride RA, Simonsen M: Cellular and Humoral Phenomena during the Inductive Phase of Parabiosis Tolerance. Transplantation. 1965; 3: 140-54. PubMed Abstract | Publisher Full Text

201. Croizat $\mathrm{H}$, Frindel $\mathrm{E}$, Tubiana M: The effect of partial body irradiation on haemopoietic stem cell migration. Cell Tissue Kinet. 1980; 13(3): 319-25. PubMed Abstract | Publisher Full Text

202. Murate T, Utsumi M, Hotta T, et al:: Hematopoietic stem cell migration and proliferation after partial body irradiation: Significant role of the spleen in hematopoietic recovery. Nippon Ketsueki Gakkai Zasshi. 1983; 46(4): 867-75. PubMed Abstract

203. F Massberg S, Schaerli P, Knezevic-Maramica I, et al.: Immunosurveillance by Hematopoietic Progenitor Cells Trafficking through Blood, Lymph, and Peripheral Tissues. Cell. 2007; 131(5): 994-1008. PubMed Abstract | Publisher Full Text | Free Full Text | F1000 Recommendation

204. F Fu J, Zuber J, Martinez M, et al:: Human Intestinal Allografts Contain Functional Hematopoietic Stem and Progenitor Cells that Are Maintained by a Circulating Pool. Cell Stem Cell. 2019; 24(2): 227-239.e8. PubMed Abstract | Publisher Full Text | Free Full Text | F1000 Recommendation

205. Bettinotti MP, Lucas DP, Ghiaur G, et al:: HLA-Class I and II Antigens are Expressed in CD34+ Cells: Implications for HLA Mismatched Bone Marrow Transplantation (BMT). Biol Blood Marrow Transplant. 2018; 24(3): S420-S421. Publisher Full Text

206. Greinix HT, Storb R, Bartelmez SH: Specific growth inhibition of primitive hematopoietic progenitor cells mediated through monoclonal antibody binding to major histocompatibility class II molecules. Blood. 1992; 80(8): $1950-6$

PubMed Abstract

207. Roberts AW, Foote S, Alexander WS, et al:: Genetic Influences Determining Progenitor Cell Mobilization and Leukocytosis Induced by Granulocyte Colony-Stimulating Factor. Blood. 1997; 89(8): 2736-44. PubMed Abstract | Publisher Full Text

208. F Ryan MA, Nattamai KJ, Xing E, et al:: Pharmacological inhibition of EGFR signaling enhances G-CSF-induced hematopoietic stem cell mobilization. Nat Med. 2010; 16(10): 1141-6.

PubMed Abstract | Publisher Full Text | Free Full Text | F1000 Recommendation

209. Cohen KS, Cheng S, Larson MG, et al:: Circulating CD34+ progenitor cell frequency is associated with clinical and genetic factors. Blood. 2013; 121(8): e50-e56.

PubMed Abstract | Publisher Full Text | Free Full Text

210. Bogunia-Kubik K, Gieryng A, Dlubek D, et al:: The CXCL12-3'A allele is associated with a higher mobilization yield of CD34 progenitors to the peripheral blood of healthy donors for allogeneic transplantation. Bone Marrow Transplant. 2009; 44(5): 273-8. PubMed Abstract | Publisher Full Text

211. B MA, M C, A B, et al:: VCAM1 RS1041163 polymorphism influences G-CSF mobilization of CD34+ cells. Haematologica. 2010.

212. Martin-Antonio B, Carmona M, Falantes J, et al:: Impact of constitutional polymorphisms in VCAM1 and CD44 on CD34+ cell collection yield after administration of granulocyte colony-stimulating factor to healthy donors.
Haematologica. 2011; 96(1): 102-9.

PubMed Abstract | Publisher Full Text | Free Full Text

213. Szmigielska-Kaplon A, Szemraj J, Hamara K, et al: Polymorphism of CD44 influences the efficacy of $\mathrm{CD} 34^{+}$cells mobilization in patients with hematological malignancies. Biol Blood Marrow Transplant. 2014; 20(7): 986-91. PubMed Abstract | Publisher Full Text

214. Schulz M, Karpova D, Spohn G, et al:: Variant rs1801157 in the 3'UTR of SDF-1 Does Not Explain Variability of Healthy-Donor G-CSF Responsiveness. PLOS One. 2015; 10(3): e0121859.

PubMed Abstract | Publisher Full Text | Free Full Text

215. Schroeder MA, Rettig MP, Uy GL, et al.: Cxcl12 G801A Polymorphisms Do Not Predict Response to Mobilization by Plerixafor in Normal Allogeneic Stem Cell Donors. Biol Blood Marrow Transplant. 2012; 18(2): S261. Publisher Full Text

216. To LB, Levesque JP, Herbert KE: How I treat patients who mobilize hematopoietic stem cells poorly. Blood. 2011; 118(17): 4530-40. PubMed Abstract | Publisher Full Text

217. F Olivieri J, Attolico I, Nuccorini R, et al:: Predicting failure of hematopoietic stem cell mobilization before it starts: The predicted poor mobilizer (pPM) score. Bone Marrow Transplant. 2018; 53(4): 461-73. PubMed Abstract | Publisher Full Text | F1000 Recommendation

218. Bhamidipati $P$, Wang $S$, Sturgill $T$, et al.: Predicting autologous stem cell mobilization failure in hematologic malignancies. Blood. 2013; 122(21): 2034. Publisher Full Text

219. Duong HK, Bolwell BJ, Rybicki L, et al.: Predicting hematopoietic stem cell mobilization failure in patients with multiple myeloma: a simple method using day 1 CD34+ cell yield. J Clin Apher. 2011; 26(3): 111-5. PubMed Abstract | Publisher Full Text

220. Kuittinen $\mathrm{T}$, Nousiainen $\mathrm{T}$, Halonen $\mathrm{P}$, et al:: Prediction of mobilisation failure in patients with non-Hodgkin's lymphoma. Bone Marrow Transplant. 2004; 33(9): 907-12.

PubMed Abstract | Publisher Full Text

221. Giralt S, Costa L, Schriber J, et al:: Optimizing Autologous Stem Cell Mobilization Strategies to Improve Patient Outcomes: Consensus Guidelines and Recommendations. Biol Blood Marrow Transplant. 2014; 20(3): 295-308. PubMed Abstract | Publisher Full Text

222. Jiang L, Malik S, Litzow M, et al.: Hematopoietic stem cells from poor and good mobilizers are qualitatively equivalent. Transfusion. 2012; 52(3): 542-8. PubMed Abstract | Publisher Full Text | Free Full Text

223. Papayannopoulou T, Nakamoto B, Andrews RG, et al:: In vivo effects of Flt3/Flk2 ligand on mobilization of hematopoietic progenitors in primates and potent synergistic enhancement with granulocyte colony-stimulating factor. Blood. 1997; 90(2): 620-9.

PubMed Abstract | Publisher Full Text

224. Anandasabapathy N, Breton G, Hurley A, et al.: Efficacy and safety of CDX-301, recombinant human Flt3L, at expanding dendritic cells and hematopoietic stem cells in healthy human volunteers. Bone Marrow Transplant. 2015; 50(7): 924-30.

PubMed Abstract | Publisher Full Text | Free Full Text

225. Brasel K, McKenna HJ, Morrissey PJ, et al.: Hematologic effects of flt3 ligand in vivo in mice. Blood. 1996; 88(6): 2004-12.

PubMed Abstract | Publisher Full Text

226. Donahue RE, Jin $P$, Bonifacino AC, et al:: Plerixafor (AMD3100) and granulocyte colony-stimulating factor (G-CSF) mobilize different $\mathrm{CD} 4^{+}$cell populations based on global gene and microRNA expression signatures. Blood. 2009; 114(12): 2530-41.

PubMed Abstract | Publisher Full Text | Free Full Text

227. F Ziegenhain C, Vieth B, Parekh S, et al.: Quantitative single-cell transcriptomics. Brief Funct Genomics. 2018; 17(4): 220-32. PubMed Abstract | Publisher Full Text | Free Full Text | F1000 Recommendation

228. F Rodriguez-Meira A, Buck G, Clark SA, et al:: Unravelling Intratumoral Heterogeneity through High-Sensitivity Single-Cell Mutational Analysis and Parallel RNA Sequencing. Mol Cell. 2019; 73(6): 1292-1305.e8. PubMed Abstract | Publisher Full Text | Free Full Text | F1000 Recommendation

229. Petti AA, Williams SR, Miller CA, et al.: Mutation detection in thousands of acute myeloid leukemia cells using single cell RNA-sequencing. bioRxiv. 2018. Publisher Full Text

230. Nam AS, Kim KT, Chaligne R, et al:: High throughput droplet single-cell Genotyping of Transcriptomes (GoT) reveals the cell identity dependency of the impact of somatic mutations. bioRxiv. 2018. Publisher Full Text

231. F Baryawno N, Przybylski D, Kowalczyk MS, et al:: A Cellular Taxonomy of the Bone Marrow Stroma in Homeostasis and Leukemia. Cell. 2019; 177(7) 1915-1932.e16.

PubMed Abstract | Publisher Full Text | Free Full Text | F1000 Recommendation

232. F Severe N, Karabacak NM, Gustafsson K, et al.: Stress-Induced Changes in Bone Marrow Stromal Cell Populations Revealed through Single-Cell Protein Expression Mapping. Cell Stem Cell. 2019; 25(4): 570-583.e7. PubMed Abstract | Publisher Full Text | Free Full Text | F1000 Recommendation

233. F Tikhonova AN, Dolgalev I, $\mathrm{Hu} \mathrm{H}$, et al:: The bone marrow microenvironment at single-cell resolution. Nature. 2019; 569(7755): 222-8. PubMed Abstract | Publisher Full Text | Free Full Text | F1000 Recommendation 


\section{Open Peer Review}

\section{Current Peer Review Status:}

\section{Editorial Note on the Review Process}

Faculty Reviews are review articles written by the prestigious Members of Faculty Opinions. The articles are commissioned and peer reviewed before publication to ensure that the final, published version is comprehensive and accessible. The reviewers who approved the final version are listed with their names and affiliations.

\section{The reviewers who approved this article are:}

\section{Version 1}

\section{Jean-Pierre Levesque}

Faculty of Medicine, University of Queensland, Herston, Queensland, Australia

Competing Interests: No competing interests were disclosed.

\section{Mariusz Ratajczak}

Stem Cell Program, Department of Medicine, Division of Hematology and Oncology, University of Louisville, Louisville, Kentucky, USA

Competing Interests: No competing interests were disclosed.

The benefits of publishing with F1000Research:

- Your article is published within days, with no editorial bias

- You can publish traditional articles, null/negative results, case reports, data notes and more

- The peer review process is transparent and collaborative

- Your article is indexed in PubMed after passing peer review

- Dedicated customer support at every stage

For pre-submission enquiries, contact research@f1000.com 